\title{
Small claims class actions: a comparative analysis of the Brazilian and American systems from the perspective of positive externalities
}

\author{
Débora Chaves Martines Fernandes
}

Advogada formada pela USP. Mestra em Direito Processual Civil pela USP. Mestra em Direito pela Harvard Law School.

\begin{abstract}
Resumo
Para que os particulares possam efetivamente obter a tutela judicial de seus direitos, algumas vezes os legisladores precisam intervir, criando mecanismos que viabilizem o ajuizamento de demandas que, do contrário, não seriam levadas aos tribunais. Uma das soluções processuais para esse problema é o que se denomina de ações coletivas com pedido ou reivindicação pequena. Neste artigo, defendemos que a dissuasão da prática de condutas ilícitas ou danosas deve ser o foco dessas soluções, uma vez que a compensação financeira individualmente devida nessas hipóteses é realmente baixa, deixando de funcionar, em si mesma, como motivação para que as pessoas atingidas busquem o Judiciário. Alguns sistemas jurídicos são mais bem estruturados para induzir a dissuasão através de ações coletivas com pedidos pequenos, bem como para gerar outras externalidades positivas, aumentando, em última análise, o bem-estar social. Neste trabalho, procuramos comparar os sistemas brasileiro e norte-americano e averiguar em que extensão cada um deles consegue produzir benefícios sociais e aumentar o bemestar. Identificado que a dissuasão não constitui o foco primário do sistema jurídico brasileiro, buscamos, ao final, propor algumas mudanças legislativas que aprimorem esse papel em debate.
\end{abstract}

\section{Palavras-chave}

Ações Coletivas; Análise econômica do direito; Externalidades positivas; Direitos individuais homogêneos; Pedidos de baixo valor.

\section{Small claims class actions: a comparative analysis of the Brazilian and American systems from the perspective of positive externalities}




\begin{abstract}
To enable the effective private enforcement of liability rules sometimes the policy makers have to interfere, creating mechanisms to allow people to litigate claims that, otherwise, would not be taken to the Courts. One of the procedural solutions to this problem is the small claims class actions. In this paper, we adopt the view that deterrence should be the focus of these policies, once the compensation is too low to motivate injured people to pursue it. Some legal systems are more equipped to induce deterrence through class litigation of small claims and to generate other positive externalities, increasing the social welfare. Here we aim to compare the Brazilian and the American systems, and to verify in what extent both class action systems are able to produce social benefits and increase social welfare. Because it is possible to identify that deterrence is not the primary focus of Brazilian legal scenario in this topic, we intend to propose some legislative changes to enhance this feature role in the debate.
\end{abstract}

\title{
Keywords
}

Class Actions; Economic analysis of law; Positive externalities; Class Actions for Damages; Small claims

\section{Sumário}

1. Introduction; 2. Private enforcement of liability rule: in which scenarios litigation is desirable and efficient; 3 . Class actions for damages: costs and benefits of aggregated litigation of small claims; 3.1. Small claims class actions in United States: the challenge of balancing costs, compensation, deterrence and other positive externalities; 3.2. Brazilian class actions and the broad access to justice model; 3.2.1. Small claims class actions in Brazil - from the collective adjudication to the individual enforcement; 3.3. Is the Brazilian model of small claims class actions economically efficient?; 3.3.1. Does it provide compensation?; 3.3.2. Does it induce deterrence?; 3.3.3. Does it generate other positive externalities?; 4. Legislative proposals to deal with Brazilian class actions' shortcomings; 4.1. Deterrence; 4.2. Compensation; 4.3. Other positive externalities; 5. Conclusion.

\section{Introduction}

The cost and benefits analysis of public enforcement and private enforcement, in order to verify the viability of fostering or constraining each of them, varies greatly through different branches of law, different moments in history and different jurisdictions. It is safe to say that some rules are enforced more efficiently - and less costly - through regulatory measures and, some of them, are better left on the hands of people who have a legal right to collect damages through litigation. 
When it comes to the enforcement of liability rules, the choice whether to privilege private over public enforcement have to take into account individual and social costs of litigation, as well as the incentives for stakeholders to bring lawsuits discussing such issues $^{1}$. For the sake of comparison, if we consider the litigation field as a market place, the amount of lawsuits should stay at an optimum level, in order to generate not only private benefits, such as compensation, but also socially desirable outcomes, such as deterrence of harmful conducts and other positive externalities ${ }^{2}$.

If the cost to adjudicate a certain claim is too high when compared to the expected benefit the lawsuit will generate to the plaintiff, it is possible that the litigation will not occur. That is what generally happens with the so-called small claims. Nevertheless, there is social value to the litigation of these claims, and here is where it is justifiable to the government to act and correct a flaw in the litigation market, by creating mechanisms to allow stakeholders to argue these claims before Courts. The class actions is one of the legislative solutions to the problem described above $^{3}$.

In the United States, the class actions system is structured to encourage private enforcement by awarding a large percentage of the funds collected in the lawsuit to the plaintiffs' attorney, the ultimate responsible for bring the class together - which can be specially hard in small claims cases ${ }^{4}$. In the American system, the cost to bring a class action is very high, in order to cover the social costs of litigation. As to the benefits, even if the individual gains are low ${ }^{5}$, the small claims class actions can generate positive social outcomes, such as deterrence, help building a strong precedents (stare decisis) database, to establish settlement ranges for future cases and helps to alleviate the burden of public agencies by allocating in the private sector some of the enforcement power/cost ${ }^{6}$. This is what we call positive externalities.

${ }^{1}$ ROSENBERG, David; SHAVEL, Steven. A Model in Which Suits Are Brought For Their Nuisance Value, International Review of Law and Economics, n.5, 1985, p-3.

2 RUBENSTEIN, William B., Why Enable Litigation? A Positive Externalities Theory of Small Claims Class Actions, UMKC Law Review, n.74, 2006, p-721.

${ }^{3}$ On the topic, see Shavell: "It should be clear that the basic points made here about he possible divergence between the private and the social incentives to bring a lawsuit would apply quite generally in respect to a more realistic description of the social costs and the social benefits of use the legal system. And given this broad interpretation, one might view various social efforts to promote or subsidize suit (availability of the class action, establishment of small claim Courts) as social solutions to problems of otherwise insufficient private motives to bring a suit." SHAVEL, Steven. The social versus the private cost to bring a suit in a costly legal system, Journal of Legal Studies, n.11, 1982, p-331.

${ }^{4}$ OLSON, Mancur. The logic of collective action: public goods and the theory of groups, Harvard Economic Studies, V. CXXIV, 1965, p-111.

${ }^{5}$ COFFEY JR, John $C$. The regulation of entrepreneurial litigation: balancing fairness and efficiency in the large class action, University of Chicago Law Review, N.54-3, Summer 1987, p-877.

${ }^{6}$ Id. supra note 2 and HENSLER, Deborah (et. alli). Class Action Dilemmas - pursuing public goals for private gain. Santa Monica, California: Ed. RAND, 2000, p-4. 
When we look to the Brazilian class actions system, it is also possible to identify the legislator's concern to grant broad access to justice - especially to claims that people would not litigate individually. Nevertheless, the way it was structured does not make it so clear that these positive externalities are present in the small claims realm. The lack of individual standing - leading to the predominance of the Public Attorneys and Attorneys Generals' offices as class actions plaintiffs -, along with the limitations to celebrate settlements and the peculiar rules for the enforcement phase of a class action for damages can dilute the deterrence effects and the other benefic social effects quoted above ${ }^{7}$.

Therefore, if Brazilian small claims class actions produce so little of these positive externalities, maybe the enforcement of liability rules through litigation - such as consumer protection rules -is an inefficient way to do it. Maybe Government intervention to foster this kind of lawsuit, instead of correcting a distortion, is creating new ones.

This paper intends to analyze the Brazilian small claims class actions, particularly regarding consumer protection, comparing it with the American small claims class actions, from the perspective of the socially desirable outcomes - such as deterrence and other positive externalities. These outcomes justify the need to create and develop a legal system that allows the adjudication of small claims, in order to match the social costs of this sort of litigation. If they do not exist, a change in the procedural rules may balance the equation and make this specific kind of lawsuit worthwhile.

The first part of the paper will analyze the principles of private enforcement of liability rules through litigation, verifying how the incentives and the costs are weight by individuals - or by any standing holder - and how the decision to bring a lawsuit and, ultimately, proceed to trial, is likely to be made. This part will explore the theories of classic law and economics, aiming to identify in which scenarios it is desirable to foster litigation as a way to deter wrongful practices.

Once the theoretical base is settled, the second part will expand the focus and work on the role of class actions as an instrument to lower the individual costs of litigation and, eventually, increase the possible gains, aiming to enable the litigation of certain matters. The analysis will compare the incentives and costs in the American and in the Brazilian system, as well standing issues and different procedural mechanisms present in each of these legal systems. One may consider these mechanisms as more or less important when it comes to induce deterrence, provoke corporate policy changes, create

7 To illustrate the sort of problem I intend to analyse the positive externality of sharing costs of enforcement with private parties is possibly mitigated in the Brazilian system, once the public attorney's offices file most of class actions. When you added that to the fact that class actions are cost free, it is intuitive to conclude that government - one way or the other - is absorbing the costs of enforcement. 
a precedent system for trials and settlements and allocate responsibility and costs of enforcement in the private sector. Special attention will be devoted to class actions for damages in the United States and its equivalent in Brazil, once the small claims litigation often occur in this sort of lawsuit.

The third part will work with the results of the analysis proceeded in the previous chapter, stressing some of the weaknesses of Brazilian class action system and proposing legislative changes. The goal is to correct the distortions in the level of litigation and the its social outcomes, especially when it comes to induce deterrence and to generate other positive externalities - such as getting the private sector involved in the enforcement of liability rules.

\section{Private enforcement of liability rule: in which scenarios} litigation is desirable and efficient

Both public entities and private parties can undertake the efforts to enforce laws understood like the systemic ability to detect and convict offenders ${ }^{8}$. Government promotes public enforcement by prohibiting certain conducts and punishing the agents who engage in harmful activities, directly or through regulatory agencies. The private enforcement happens through litigation, when a private party brings a lawsuit seeking for compensation for the violation of a certain right ${ }^{9}$. Deterring future violations is one of the positive externalities ${ }^{10}$ of the litigation market, as we shall see below.

In the private enforcement scenario, part of the costs are shifted to the parties in litigation instead of been absorbed by the Government, but this is not it's only positive feature. Several scholars, and even government regulators themselves, reinforce the benefits of private enforcement because the public ability to enforce the law is frequently constrained by limited resources, confliction group interests and political pressure, not to mention the fact that, sometimes, private litigants have more economic incentive to pursue their rights. Consequently, the existence of rules to foster litigation provides an

8 LANDERS, William M.; POSNER, Richard A. The private enforcement of law, Journal of Legal Studies, n.4, 1975, p-1.

${ }^{9}$ SHAVELL, Steven. Foundations of Economic Analysis of Law. Cambridge, Massachusetts: Belknap Press, 2004. p-391.

10 In the definition of Gregory Mankiw, an externality is a byproduct of the activity of one person such as consumption or production of a good that affect the well-being of an uninvolved person. The term externality comes from the fact that someone external to the action or transaction is affected by the production of consumption of the good. The externalities can be negative, if the activity creates costs -or harms - to the uninvolved people; and they can be positive, if they create benefits for uninvolved people. See MANKIW, Gregory. Principles of Microeconomics. $7^{\text {th }}$ ed., Nashville, Tenessee: South-Western College Pub, 2014. 
extra incentive for people to comply with laws and regulations ${ }^{11}$, once they can be hold accountable for the harm they cause and compelled to pay damages.

For these reasons, it is desirable, in order to induce an optimal level of care throughout society, to allow and to encourage private enforcement of liability rules. Still, to calibrate the optimum social level of litigation, in which the social costs do not exceed the social benefits, it is necessary to make some further calculation.

Envisioning the litigation system through the perspective of the economic analysis of law begins with the premise that lawsuits are transactions in a particular marketplace: the legal system ${ }^{12}$. In this market, "plaintiff trades her claims for money, defendant trades its money for finality: the lawsuit is a transaction in which res judicata is bought and sold"13. These exchanges generate both private and social costs and benefits and, in a rational choice model ${ }^{14}$, there should be a proper way to arrange the litigation system in order to achieve a socially optimal amount of litigation ${ }^{15}$.

To achieve this optimum, the private incentives to litigate as well as the socially desirable level of litigation must be taken into account ${ }^{16}$. It is expected that a plaintiff will sue every time the payment he expects to receive from the defendants exceeds the costs of bringing the lawsuit; the difference between these two numbers is the private benefit of litigation ${ }^{17}$. The social benefit is the effect it will have in the behavior of that specific defendant and other potential defendants towards avoiding harmful practices in the future - the deterrence effect ${ }^{18}$. The social costs of litigation, as a component of the equation, involve the plaintiffs' costs to bring the lawsuit, the defendants' costs to fight it and the States' costs to maintain the court system working ${ }^{19}$.

The misalignment between the private and the social perspective is the main cause for the unbalance in the socially optimal amount of litigation, understood as the amount that enhances positive externalities ${ }^{20}$, such as deterrence. When faced with the decision of whether or not to file a lawsuit, the plaintiff will consider only the costs and benefits he will individually experiment. For this reason, he may file the lawsuit when his benefits are

${ }^{11}$ HENSLER, Deborah (et. alli), Id supra note 6.

12 RUBENSTEIN, William B. A Transactional Model of Adjudication, Georgetown Law Journal, n.89, 2001. $p-371-373$.

$13 \mathrm{Id}$. at 419 .

${ }^{14}$ We adopt in this paper the traditional rational choice model of economic analysis of law. See SHAVELL, Steven, supra note 9 and POSNER, Richard A., Economic Analysis of Law. $7^{\text {th }}$ ed., New York, New York: Aspen Publishers, 2003.

${ }^{15}$ SHAVELL, Steven, supra note 9, at 391-92.

16 Id. at 392.

17 Id. at 390.

18 POSNER, Richard A., supra note 15, at 530.

19 See SHAVELL, Steven, supra note 3; LANDERS, William M.; POSNER, Richard A., supra note 8, at 235.

${ }^{20}$ MANKIW, Gregory, supra note 10. 
higher than his costs, but regardless of the total cost associated with the lawsuit - which might make litigating this issue socially undesirable. In the same sense, when the costs for the plaintiff is higher than the expected benefits, he may not sue, and the wrongful behavior of the defendant will go undeterred - and no social benefits will result from this behavior $^{21}$.

This unbalance can be considered as a market failure, which calls for policy-makers intervention in order to pursue equilibrium in the amount of litigation and the positive externalities it generates to society ${ }^{22}$. In the scenario that will be analyzed in this opportunity, some claims are so small in value that they would not be litigated individually. Nevertheless, the absence of individual litigation would represent a failure, leading to a low production of positive externalities, which include, but are not limited to, the deterrence of future harmful behavior ${ }^{23}$. The class action mechanism, which allows the aggregate litigation of claims, represents a legislative intervention in the "individual litigation market" 24 , with the goal of preserving the benefic social outcomes of this sort of lawsuit.

Several different legal system around the world adopt the class action - or at least some sort of collective action - as a solution to the problem of under litigation of small claims. That indicates that policy-makers attribute an ex-ante value to aggregate litigation, based on the premise that it has potential to generate positive externalities, higher than an ex-post value based on actual results of the choice whether or not to allow this sort of lawsuit ${ }^{25}$. Nonetheless, the existence of an intrinsic value to small claims class actions should not prevent discussions about the best way to structure the litigation system - or about what should be a priority in order to achieve efficiency. The comparison between the American and Brazilian small class action systems will highlight the importance of these institutional choices.

\section{Class actions for damages: costs and benefits of aggregated}

\footnotetext{
${ }^{21}$ And the reverse is also true. Sometimes there is a large volume of litigation with no or low deterrence effects. Shavell uses the example of the automobile accidents, which makes approximately half of all the tort litigation. Nevertheless, there are several other incentives not to cause accidents (apart from the threat of litigation), such as criminal penalties, the possibility of personal injuries and patrimonial damages. Moreover, the deterrence effect in this field is also undermined by the liability insurance nearly everyone has. See SHAVELL, Steven, supra note 9, at 395.

22 RUBENSTEIN, William B., supra note 2 , at 722 .

${ }^{23}$ Id. at 723.

24 Id. at 722,723 .

${ }^{25}$ See HAY, Bruce L., Procedural justice - ex-post v. ex-ante, UCLA Law Review, n.44, 1997 and ROSENBERG, David. Class Actions for Mass Torts: Doing Individual Justice by Collective Means, Indiana Law Journal, n.62, 1987, p-561-567.
} 


\section{litigation of small claims}

As discussed above, we have to take into account two different dimensions when it comes to private enforcement of liability rules: the plaintiff's perspective and the society perspective. In a risk neutral environment, the plaintiff will sue when the costs he will have to bear are lower than the benefits he envisions to receive in the end of the suit (no matter if the suits ends in settlement or goes to trial) ${ }^{26}$. On the other hand, the legislator is supposed to foster litigation whenever the social benefits are deemed to surpass the social costs of the lawsuit.

To make sure that the amount of litigation will be as near as possible to an equilibrium, legislators and policy-makers elaborate procedural solutions in order to enable the litigation of small claims, which would probably not be taken to Courts in the absence of these mechanisms. The goal is to enhance the social benefits of the private enforcement, by promoting deterrence of undesired behaviors, as well as other positive externalities $^{27}$. The small claims class actions are one of these solutions. They increase the incentives to litigate by making the mediate or immediate benefits to surpass the costs of the lawsuit.

\subsection{Small claims class actions in United States: the challenge of balancing costs, compensation, deterrence and other positive externalities}

The class action system in the United States is the result of centuries of legal history, starting in the medieval England with the need to avoid impracticable joinders, evolving to the multimillion dollars awards in the second half of the $20^{\text {th }}$ century and, finally, experiencing the recrudescence of the criteria for classification in current time ${ }^{28}$. Joseph Story made notes on the evolving character of the class actions, as well as the different

${ }^{26}$ SHAVELL, Steven, supra note 9 , at 4.

27 RUBENSTEIN, William B., supra note 2 and CAPPELLETTI, Mauro; GARTH, Bryant. Access to Justice: A world survey. A. Giuffrè, 1978.

${ }^{28}$ Stephen Yeazell develops a very comprehensive historical panorama of the class actions in the Common Law countries, from the English group litigation in the $12^{\text {th }}$ century to the reforms in the American class action in the sixties; see YEAZELL, Stephen C. From medieval group litigation to the modern class action. New Haven: Yale University Press, 1987. When it comes to the recent events involving the class action doctrine, reference can be made to the recent case involving gender discrimination on Walmart, in which the Supreme Court reversed the class certification under Rule 23(b)(2) by saying that commonality must be accessed in the certification phase, considering not only a common issue, but also a common remedy. These requirements made more difficult to certify a class action, at least under the cited rule. See Walmart Stores Inc. v. Dukes et al, 131 S.Ct. 2541 (2011). 
perspectives to what should be its focus and its function:

“(...) to consolidate suits that otherwise be brought (and thus to reduce the caseload of the judiciary) or to facilitate the bringing of suits that would otherwise not be brought because of the individual stakes are too small (and thus to increase the accessibility of adjudication). The first alternative aims at reducing existing litigation, the second at enabling potential litigation to occur; at some level the two stand in tension"29.

The idea behind the small claims class action has been a part of the rationality of the American system from its beginning. From the second half of past century on, the discussion changed to what purpose does the small claim class action serves, once the gains of the individual class members were nearly irrelevant compared to, for example, the amount plaintiffs attorneys' were awarded ${ }^{30}$. This reality brought a clash of two concerns: (i) the possibility of undercompensating damages and; (ii) the threat to create conditions for the arousal of a very profitable market for plaintiffs attorneys' driven by the possibility of being awarded a large amount in attorney's fees ${ }^{\prime 31}$. Considering these points, a solid tendency started consolidating in the literature, stating that the focus of the small claims class action should not be the individual costs and benefits. Instead, such lawsuits should focus on the social benefits they may generate, particularly the deterrence effect ${ }^{32}$.

The logic of this argument draws its legitimacy from the law and economics principles discussed in the prior section, by saying that if individual compensation were the most important feature in this context there would be enough incentives for the plaintiffs to litigate the claims by themselves. If a governmental interference is need to keep the litigation closer to the optimum, allowing the aggregate litigation of small claims and, hence, correcting the flaw in the litigation market, the focus should be on the beneficial effects this rules will have on society as a whole ${ }^{33}$.

To this extent, despite the ongoing discussion and points where there could be improvements ${ }^{34}, \mathrm{I}$ believe that the American class action system is equipped with rules

\footnotetext{
${ }^{29}$ YEAZELL, Stephen, supra note 28 , at 31,39.

30 GYLES, Myriam; FRIEDMAN, Gary B. Exploding class action agency cost myth: the social utility of entrepreneurial lawyers, University of Pennsylvania Law Review N. 155, 2006-2007, p-103-104. See also SHERMAN, Edward F. Consumer Class Action: Who Are the Real Winners?, Maine Law Review, n.56, 2004, p-223-233.

${ }^{31}$ GYLES, Myriam; FRIEDMAN, Gary B., Id. Supra note 30.

32 RUBENSTEIN, William B., supra note 2, at 725.

33 ROSENBERG, David. Class Actions for Mass Torts: Doing Individual Justice by Collective Means, Indiana Law Journal, n.62, 1987. P-560-561.

${ }^{34}$ Among the discussions around the mass tort class actions and small claims class actions is the possibility of transforming this sort of litigation in mandatory, following principles of bureaucratic justice of standardization of the damage amounts and transference of the control over the lawsuit to the lawyers instead of the plaintiffs themselves. Some scholars contend that this mechanism would enhance the distributional goals of the Class Actions, while promoting more efficient private enforcement. Moreover, these mechanisms could help to avoid collective action problems, such as
} 
that aim to maximize its potential to compensate and to generate deterrence, as well as other positive externalities, especially regarding small claims.

The solely existence of a procedure that allows the aggregate litigation of claims that otherwise would not reach the Courts, induces a higher level of care among potential defendants, because they know they can be held liable and pay damages even if the individual stakes of the plaintiffs are too low $^{35}$.

But the threaten is only effective if there are enough incentives file this kind of lawsuit, and the American class action model adopted a system of economic incentives (high risk/high return) to litigate aggregate claims, which is particularly interesting when it comes to small claims. It is structured around the idea of balancing asymmetrical stakes by allowing the class to trust the conduction and great deal of the risk of the case to the class' attorneys, in exchange of a percentage in the total amount recovered by the class ${ }^{36}$. The fee arrangement, along with the fact that most class litigation are financed by law firms, raise the stakes on the class side, incentivizing the attorney to fiercely litigating the common question ${ }^{37}$ as well as maximizing the class gains - once their fees will be a percentage of this aggregate recovery ${ }^{38}$. These rules foster litigation of small claims through class action and, as consequence, increase the possibility of detection of harmful conducts and the deterrence of future analogous behavior ${ }^{39}$.

Besides the incentive to litigate, other feature that enhances the deterrence effect is that the compensation fund, either if a decision award damages to the class or if the parties reach a settlement, will be created by the losing defendant immediately and with the whole amount of damages. The internalization of the costs of the wrongful behavior will occur right after the awarding to the class - or immediately after the approval of the

free riding, and increase the scale economy of litigation on the plaintiffs' side. See ROSENBERG, David, supra note 33. See also CAMPOS, Sergio J. Class Actions All the Way Down, Columbia Law Review, n.113 Sidebar 20, 2013, available at: http://www.columbialareview.org/wpcontent/uploads/2013/02_Campos.pdf

${ }^{35}$ RUBENSTEIN, William B., supra note 2, at. 724.

${ }^{36}$ CAMPOS, Sergio J., supra note 34 , at 26.

37 Id. at 26-27.

38 NAGAREDA, Richard A., Mass Torts in a World of Settlement, Chicago, Illinois: University Of Chicago Press, 2007, p-219-249. See also RUBENSTEIN, William B. The Largest Fee Award - ever!, Class Action Attoneys' Fees Digest, September, 2008, available at http://www.billrubenstein.com/writing.html .

${ }^{39}$ As much as the system of high risk (costs)/high returns to the class lawyers may incentivize the aggregate litigation in small claims class actions, some problems are frequently related to the cost of civil procedure and they may be observed in the realm of the class actions too. One of them is that these costs and risks may induce plaintiffs to settle and give up meritorious claims only to avoid incurring in crescent expenses. This may harm not only adequate compensation, but also affect deterrence, by underestimating the amount of damages. See ROSENBERG, David, A sampling-based system of civil liability, Theoretical Inquiries in Law, Vol. 15, Issue 2, June 2014, p-635. 
Court on the settlement amount. After that, the class representative and/or the class council will administer and divide this amount among the class members ${ }^{40}$.

The deterrence aspect of this kind of lawsuit is enhanced by the fact that several solutions have been envisioned - both by scholars and by judges - to distribute the surplus left on the fund when the class members don't even come forward to claim their share of the amount awarded in the class action decision or in the aggregate settlement. Some of the possibilities are (i) to divide the surplus among the member who showed up inducing more adherence of class members in future opportunities, with the promise of a bigger reward - and (ii) to donate the unclaimed amount to charitable entities with a goal compatible to the litigious topic ${ }^{41}$. As much as, in the end of the day, who gets the money is not as important as the fact that the injurer internalized the costs of his wrongful behavior, it is important to discuss alternatives to the direct compensation of the class members. This will grant legitimacy to the whole system - once the concept of compensating the damage inflicted on the injured party is in the base of individual and even class litigation in this field ${ }^{42}$.

Finally, going beyond deterrence, some American scholars highlight that litigating small claims through class actions generates other positive externalities that enhance its importance, summarizing them into four categories: (i) decree effects; (ii) settlement effects; (iii) threat effects; and (iv) institutional effects.

The decree effects, based on a the American legal system of stare decisis, would make the resolution of future cases involving the same topic more efficient, once the decision in the first case will set a precedent. It may most immediately induce the injurer or entities in the same position as the one prosecuted in the first case - to cease the practice affecting the group, in order to avoid litigation. Moreover, it can preclude the relitigation of similar factual issues, due to collateral estoppel rules ${ }^{43}$. Once only a final Court judgement can induce the decree effects, and the culture of settlement is very strong in the United Stated, it is also possible to point out some positive effects regarding class action settlements, such as the informative exchange among same situated parties, who can use the parameters of one settlement to their advantage in similar cases. Overall, the creation of settlement ranges may reduce litigation costs and shape the behavior of the

${ }^{40}$ FRIEDENTHAL, Jack H. et. al., Civil Procedure: Cases and Materials, Eagan, Minnesota: WEST, 2013, p-747-752.

${ }^{41}$ REDISH, Martin H.; JULIAN, Peter; ZYONTZ Samantha. Cy Press Relief and the Pathologies of the Modern Class Action: A Normative and Empirical Analysis, Florida Law Review, n.62, 2010, p-617.

42 Id. at 620.

${ }^{43}$ RUBENSTEIN, William B., supra note 2 , at 722-23. 
parties in future cases, by inducing litigants to settle or even to adjust their policies to avoid the filing of the class action in the first place ${ }^{44}$.

The threat effect, as already commented above, is a direct result of the possibility of adjudicating small claims through class actions, once the risk of litigation is something that parties must weight when undertaking a cost-benefit analysis of any activity or behavior $^{45}$. If the damage caused is so small that the stakes of the injured parties are too low, the chance of the injurer to take measures to avoid these damages is also too low. On the other hand, the existence of a mechanism that allows aggregate litigation of small claims changes the analysis and may increase the level of care ${ }^{46}$.

Other positive externality of the development of private law enforcement net are the institutional effects. The way the American system structured the procedural costs, as well as the attorney fees' rules, allows a real division of work efforts to enforce liability rules among public and private sectors. If this division will be cost effective will depend on the efficiency of the private enforcers, but other benefits, like the possibility of being immune to political pressure, as well as to ideological and economic capture, allows us to see this arrangement as a positive externality ${ }^{47}$.

After a brief revision of the literature on American class actions, it becomes clear that several points still raise many issues and doubts about what should be its primary focus - compensation or deterrence. There is also ongoing discussion on how to perfect the mechanism to reach these goals, or how to enhance the effectiveness of private enforcement by diminishing agency costs ${ }^{48}$. However, apart from these points of interest, the concern to generate positive social value permeates the class action rules, and it is not easy to observe this particular feature in other countries.

\subsection{Brazilian Class Actions and the broad access to justice model}

The uprise of class actions in Brazil happened in the last three decades under the idea that the access to justice must be as broad as possible. To the view of several legal scholars in different Civil Law countries, collective and class actions would allow people to have a fair

\footnotetext{
44 In this particular point, there are several other discussions about the publicity of settlement's outcomes. To avoid the creation of a settlement range or, in other words, a precedent effect in settlements, many defendants - mainly corporations - fight to keep the agreements as private and confidential as possible. On this topic see FROMM, Blanc. Bringing Settlement out of the Shadows: Information about Settlement in an Age of Confidentiality, UCLA Law Review, n. 48, 2001, p-663.

${ }^{45}$ RUBENSTEIN, William B., supra note 2, at 724. See also CALABRESI, Guido. The Cost of Accidents: $A$ legal and Economic Analysis, New Haven, Connecticut: Yale University Press, 1970.

${ }^{46}$ RUBENSTEIN, William B., supra at 724.

47 Id. at 725.

${ }^{48}$ COFFEY JR., John C., supra note 5.
} 
hearing and a more expedite adjudication in cases that otherwise would not get to Courts, generating both individual and social benefits ${ }^{49}$.

The enactment of the Public Civil Action Act - which created the Brazilian class action in 1985 - was one of the legislative outcomes of this movement to broaden the access to justice and to vent what Brazilian scholars call "socially restrained litigation"50. This act made possible class litigation to collect damages or seek for injunctive relief regarding claims that could not be severed and individualized. Legal scholars categorized these as diffuse and collective rights ${ }^{51}$. In 1990, with the enactment of the Consumers' Protection Code (Act n. 8.078/1990), class actions to seek damages and injunctive relief ${ }^{52}$ on behalf of a class of people whose rights could be identified and individualized - the parallel to the class actions for damages in the United States - became possible ${ }^{53}$.

Besides allowing the collective adjudication of claims - and the adjudication of collective claims -, the new legal regime created a series of incentives for litigation using these new procedural rules. The main incentives were the removal of barriers to access the Courts - particularly the technical barriers and the economic barriers.

The legislator tried to remove the technical barriers by choosing as standing holders public and private entities that, allegedly, has expertise in most of the subject matter discussed in class actions - therefore denying standing to file this sort of lawsuit to the person who actually suffered the injury. This measure was supposed to eliminate the transactional coasts an individual would have to bear to file a class action, such as,

${ }^{49}$ Class actions in Brazil had a direct influence from the Italian cycle of congresses in the 70s - Pavia (1974), Salerno (1975) Florence (1979) - in which several Italian legal scholars discussed the need for new procedural means to grant the broad access to justice, taking as one of the possible solution to the problem of mass litigation, small claims litigation and the need to level the plain field between repeat players and eventual litigants. See CAPPELLETTI, Mauro; GARTH, Bryant, supra note 6.

50 The "social restrained litigation" was an expression created to refer to small claims, which would not be brought to Courts once the individual stakes are so small. Other measures taken by the Brazilian legislator to try to solve this problem, was to create the small claims Courts (Act. $\mathrm{N}$ 9.099/95) in which there are no state fees or need for an attorney to litigate claims up to a certain amount of money (approximately 8 thousand dollars).

51 In Brazil the rights of a group of people were divided in three categories: (i) diffuse rights, regarding rights that belongs to everyone in the community and, at the same time, to no one in specific - the right holders are unidentifiable as individuals but are connected to each other by a factual circumstance - such as the right of a clean environment against pollution in a particular neighbourhood; (ii) collective rights, which are also indivisible and belonging to a group, but the group is gathered by a previous legal relationship, such as being consumers of a particular service (banks, insurance companies, for example); (iii) homogenous individual rights, which are individual rights that result from the same harmful conduct and may be litigated in an aggregate way, via class action. Some authors identify the categories described above with the class action types in United States under Rule 23 (b)1, (b)2 and (b)3, respectively. See GIDI, Antonio, Class Actions in Brazil: A Model for Civil Law Countries, 51 University of Houston Public Law and Legal Theory Series, n.51, 2006-A-11, p-312.

52 When the Court grants an injunctive relief, the party is required to stop a harmful activity or to take an action in order to prevent or repair the damage caused.

53 The Consumer protection code encompasses a series of procedural rules that applies equally to all of collective interests' lawsuits, not only the ones with claims regarding consumer protection, once in the articles 109 to 117 it amends the Civil Public Action Act. 
acquiring the knowledge that the adjudication of his small claim is possible and about the best way to do so.

As discussed above, to reduce the technical barriers, the American class action system has mechanisms to incentivize specialized lawyers and law firms to pursue the adjudication of a class action, even if its individual claim value is too small. In contrast, most of the entities that have standing to file a class action in Brazil, somehow, belong to the public sector. They are the office of the Attorney General, the public attorneys - acting on behalf of the Government, the states, the municipalities and entities that belong to the public administration (government owned companies, for example) - and civil associations that exists for more than one year and comprises among its goals the defense of the rights discussed in the class action ${ }^{54}$. The civil associations are the standing holder that does not fall directly under the government power, for this reason, as I indent to explore in the next chapters, they are the only way to engage in genuinely private enforcement through class actions in Brazil.

As to the economic barriers, the way the Brazilian class action system found to circumvent this issue was to eliminate all costs of adjudication. The standing holders will not have to pay for Courts fees that applies to all other lawsuits ${ }^{55}$, will not have to pay for expert fees - if any technical evidence is need in the course of discovery - and they will not even have to pay for the defendants attorneys' fees if they lose ${ }^{56}$. If is safe to say that the plaintiffs litigate the class actions in Brazil in a risk free scenario, at least regarding direct costs of adjudication.

Considering these incentives, the class actions - especially the ones discussing small claims - seem very appealing when compared to a regular individual lawsuit, once it downs to zero the costs of private adjudication, allowing the litigation to occur.

\footnotetext{
${ }^{54}$ Article 82, IV of the Consumers Protection Code (Act n. 8.078/1990) and Article 5 of the Public Civil Action Act (Act n. 7.347/1985). The idea with the time limitation is to try to verify that the association is compromised with the defense of collective rights and that it will allegedly be an adequate representative. In my opinion, it is a long shot, which does not really guarantee that the interest of the absentees will be well represented or effective to avoid fraud. See FERNANDES, Débora Chaves Martines. Controle judicial da representatividade adequada das associações civis, unpublished masters' degree dissertation; University of São Paulo (Brazil), 2013.

55 The procedural costs in Brazil are determine by state law, so each state have fees that fit their needs to keep the Court system running. They are paid by the party that gave cause to each of the procedural phase - the plaintiff pays fees to file the suit, the party that asked for some discovery procedure (such as expert witnesses) pays for it, the losing party pays for the costs to appeal to the appellate court. To have a broad idea of Brazilian costs, see the research made by the National Council of Justice about the possibility of creating uniform costs in the whole country, available at www.cnj.jus.br/dpj/seer/index.php/CNJA/article/view/36 .

${ }^{56}$ The Brazilian legal system adopts the English rule (or fee-shifting rule) for attorney's fees, in which the losing party pays the attorney's fees from the party, as well as all the litigation costs. The exception to this rule is when there is some kind of exemption of costs - like in the class action system or when the party shows he is poor and cannot bear the costs of litigation without fall in harsh financial conditions (Act n. 1.060/1950).
} 
Nonetheless, if this kind of lawsuit benefits society as a whole, the analysis should lay on a number of other factors in order to access if the social costs are in balance with social benefits, therefore, justifying the incentives provided by the legislator and the increase of litigation.

In any event, it is possible to begin this analysis with the premise that, in Brazil, the class action system seems to create a great load of social costs without reversing many gains to the society as a whole - or even to the individual class members.

\subsubsection{Small claims class actions in Brazil - from the collective}

\section{adjudication to the individual enforcement}

Class actions for damages, the gender that include the small claims class actions as its species, are defined by Brazilian legal scholars as a procedural instrument that allows the aggregate litigation of claims that result from the same event or series of events, rather than litigation of a collective right ${ }^{57}$. Its enactment is permeated with the idea of bringing to the Courts the claims that would not be isolated litigated - either for economic or informative issues ${ }^{58}$.

The procedural rules that govern the class actions for damages are in the Consumers' Protection Code, although they apply to lawsuit discussing other subject matters. They reproduce the structure of the classic individual lawsuit - with a pleading stage, discovery, and trial by court, judgment and appeals. As to the parties, there are some fundamental differences between the individual lawsuit and the class action for damages. One of the selected standing holders will file and conduct the lawsuit until its final judgment instead of the injured party. The injured individual, as well as other interested parties, can intervene in the lawsuit ${ }^{59}$. Moreover, if the office of the Attorney General is not the plaintiff, it will be notified of the filing of the suit and will oversee the whole procedure, in a capacity called custos legis - a Latin expression to designate someone who is responsible to verify if the law is being obeyed ${ }^{60}$. The idea is to guarantee

\footnotetext{
${ }^{57}$ Brazilian scholars use to call these rights "collective by accident", see GIDI, Antonio, supra note 51. See also LEONEL, Ricardo de Barros. Manual do Processo Coletivo. 2. ed. São Paulo: RT, 2011 p-98. 58 LEONEL, Ricardo de Barros, supra note 56.

${ }^{59}$ Although the Article 94 of Brazilian Consumer Code uses the term joint part, what implies that the person will act in the same capacity of the party (the same as in the joinder rule 20 of the Federal Rules of Civil Procedure), it means that the person will intervene as interested party (the same as in the intervention rule 24 of FRCP).

${ }^{60}$ Article 5o, $\S 1$ - The office of the Attorney General, if not party of the lawsuit, will act in the capacity of overseer.
} 
that the adequacy of representation of the absentees, once the judicial review of this particular feature is not a legal requirement ${ }^{61}$.

The structure of standing changes after the final decision, in the enforcement phase. If the judgment is for the plaintiffs, the decision rendered by the Court - either the trial court or the court of appeals - will always be generic, recognizing the liability of the defendant and commanding the compensation of damages and/or entering the injunctive reliefs sought by the plaintiffs ${ }^{62}$. This judgment can be enforced both by the injured individual - the components of the class - and by the any of the standing holders, in the following ways.

The injured people will require a certificate to the Court that judged the class action- this certificate will contain the text of the decision and the information either the judgment is final or if there is any appeal pending in appellate Courts ${ }^{63}$. With this document, the person will file a new lawsuit in order to collect the amount awarded in the class action judgment. This individual lawsuit will not discuss the defendant's liability once it has been established in the class action - but it is possible for the defendant to present new defensive arguments, regarding the condition of the plaintiff (if he or she really should be considered part of the class) and the value of damages.

If after one year from the final judgment the number of people enforcing the judgment and collecting damages is deemed insufficient - considering the dimension and the severity of the damage -, the standing holders who can originally file the class action will be legitimate to enforce the judgment, by promoting what is called collective enforcement ${ }^{64}$. This procedure will give the Court power to arbitrate what should be considered a fair amount to represent the compensation for all the damage caused, this amount will be designated to a public fund, which exists to cover the social damages to consumers, investors, environment, cultural heritage of a particular site, and so on ${ }^{65}$.

\footnotetext{
${ }^{61}$ FERNANDES, Débora Chaves Martines, supra note 53.

${ }^{62}$ An injunctive relief in Brazil can either be a command, issued by the Court, for the party to cease a certain activity or a command that it engages in some activity (Article 461 of Brazilian Rules of Civil Procedure).

63 The information about pendent appeals is important because, in certain situations, the winning party can start the enforcement phase before the final decision by the appellate Courts. Nevertheless, any payment made by the losing party will be controlled by the Court, in an account linked to the lawsuit, until its final decision. The idea is to guarantee that the losing party will comply with the decision, when it comes. (Article $475-0$ of the Brazilian Rules of Civil Procedure).

${ }^{64}$ Article 100 of Brazilian Consumers Protection Code (Act n. 8.078/1990) - If after one year from the final judgement there are not enough individuals or interested people enforcing it, considering the dimension and the severity of the damage, the standing holders described on article 82 will promote the collective enforcement of the decision.

65 This public fund was created in 1985 to manage the money from payments made in class actions, collective settlements and private donations. It is managed by a board integrated by representatives of the office of Attorney General, the cabinet for urban development and environment, the cabinet for cultural development, the cabinet for industry and commerce, the cabinet for agricultural development, the cabinet of science and technology and from civil associations. It was created in the
} 
From this brief depiction of Brazilian class action for damages, it seems intuitive that the policy makers intended to prioritize compensation, by giving the class members the preference to enforce the judgment and collect the damages. Nevertheless, some level of concern about the deterrence effect is present, ensuring that one of the standing holders will be able to enforce the decision if the amount collected by the injured individuals is not enough to discourage the harmful activity - even if no one gets directly compensate.

The question this paper will try to answer is if the structure of the system as a whole allows this rules to work. Does these rules provide compensation of damages, deterrence of harmful practices and other positive externalities to society in practice?

\subsection{Is the Brazilian model of small claims class actions economically}

\section{efficient?}

As pointed out before, the economic analysis of law is one of the possible ways to verify the efficiency of legal rules, by accessing the way they mold human behavior and how much social welfare they generate when applied ${ }^{66}$. Taking the theoretical basis of the law and economics approach, I intend to check the economic efficiency of Brazilian model of small claims class actions, verifying if the social and individual benefits it generates are able to justify the costs it gives cause - and that are spread through society.

\subsubsection{Does it provide compensation?}

The idea that permeates the small claims class action, both in United States and in Brazil, is to aggregate the litigation of claims that, otherwise, would probably not make to the Courts, once the costs are higher than the expected benefit. One of the goals is to compensate the class members, even if their losses are so small that alternative ways to provide this compensation are required. In United States, one of the solutions to compensate small losses is the coupon settlement, although this solution is quite questionable from the deterrence perspective ${ }^{67}$.

Public Civil Action Act (Act n. 7.347/1985) and further regulated by the governmental decree $n$. 92.302/1986).

${ }^{66}$ SHAVELL, Steven, supra note 9, at 391-92.

67 The coupon settlement was a way developed in the everyday praxis of class actions in USA, in which the parties in a class action reach an agreement in which the class members receive a coupon to spend in goods or services provided by the defendant, instead of a cash award. It is deemed as a questionable way to settle class claims because it would not have a real deterrence effect, once the class members would ultimately consume from the defendant, who would not have to directly internalize the costs of the damage caused. See 28 U.S. Code $\S 1712$. See Christopher R. LESLIE, Christopher R. The Need to Study Coupon Settlements in Class Action Litigation, Georgetown Journal of Legal Ethics, n.18, 2005. p-1395. 
In Brazil, the creation of an individual enforcement phase, in which the person injured has to file a new lawsuit to specify a generic command in the class action decision, is a considerable barrier to compensation. That happens because, as a certification phase does not exists, the class member will have to prove that he belongs to the class and to what extent the defendant behavior affected him. Therefore, there is a pleading phase, a discovery phase and a new judgment - in which the judge will assert if the person belongs to the class and how much he or she should receive. Moreover, as now the class member is litigating on his own behalf, he does not have the rewards of the class action standing holders regarding exemption of costs - so, he will have to pay state fees and attorneys' fees as well ${ }^{68}$.

If the class member did not have enough incentives to litigate individually a certain claim because the expected benefit was too small, he will probably don't have any incentives to enforce the class action decision. That happens because, even if most part of discovery was made in the first phase - and substantial part of the costs were absorbed by the system -, the class member will have to bear, at least, part of the costs, such as the fee to file the lawsuit ${ }^{69}$, not to mention attorney's fees. Therefore, the system as designed will probably fail in providing direct compensation to the harmed individuals.

Brazilian judges tend to try to correct this distortion by issuing injunctive reliefs when deciding a small claim class action. Other than asserting the liability, the judge can command the defendant to take actions to compensate the class members. For example, if a judgment in a class action is entered against a bank, deeming as illegal a certain fee charged from its clients, instead of just state the illegality of the fee and the liability of the defendant, the judge can command the bank to return the amount to each of the clients, plus interests ${ }^{70}$.

Civil associations, as well, try to pool the claims of some of the class members and enforce them all together, as a way to cut costs and collect the damages. The problem with this solution is that, in the enforcement phase of the class action, the association can only act on behalf of its associates - what limits considerably the scope its action ${ }^{71}$. The

\footnotetext{
68 Unless the class member can prove he is poor, by the criteria established in the Act $1.060 / 1950$. In this case, he will be exempted of the payment of fees.

69 The legal fee to file a lawsuit is uniform among Brazilian states and it is calculated in $1 \%$ over the actual or expected value of the claim. However, each one of them has a minimum requirement, if the value of the claim doesn't reach this threshold. In São Paulo, this minimum nowadays is R\$ 106,25 (approximately 34 dollars). Although the value is not so high, it can be higher than several individual small claims.

70 There are some problems for the defendants to comply with these commands. As the class actions use to take long before a final judgment, it is often difficult to identify what is the period of time in which the harmful activity was in place, who was actually affected by it, and so on.

${ }^{71}$ As the associations are deemed as adequate representatives by the legislator, they can file the class action on behalf of the whole class - not only on behalf of the people who associated to it. Nevertheless, for compensation purposes in the enforcement phase, the association will have to act 
other standing holders can only promote the collective enforcement, which does not provide direct compensation of the class member.

Considering this scenario, one can say that small claims class actions are not fit to promote direct compensation for the class members, once it fails to effectively remove the economic barriers to adjudication. Nonetheless, it is important to discuss if this sort of lawsuit have the deterrence effect as one of its outcomes, what would keep the interest in fostering litigation even if the compensation goal is not being achieved.

\subsubsection{Does it induce deterrence?}

As discussed on part II, the general idea of deterrence through litigation is holding the defendant liable for a certain harmful activity and making him pay damages to the plaintiffs and, hence, internalize costs. In other words, the result of a prospective litigation has to pose a threat big enough to make the defendants investing in taking an optimal level of care and avoid the same practice in the future ${ }^{72}$. The structure of a small claim class action in the United States, in which the defendant - either after the judgment or the settlement - sets a fund to compensate the plaintiffs, give the defendant an immediate view of the amount that will be paid as damages, independently if the class members will claim these values in the future.

The fact that class actions' judgments in Brazil are a general command, asserting or not the liability of the defendant and postponing the quantification of the amount to be paid in damages to the enforcement phase have a direct impact on the deterrence effect. The defendant does not have the exact dimension of the cost he will have to internalize and, hence, calculate the costs and benefits of the harmful activity - he can only estimate and make provisions ${ }^{73}$. Moreover, there is not even a guarantee that the defendant will actually have to pay any amount of money as damages, either to the class member or to the public fund.

Regarding the individual enforcement of the collective judgment, conducted by the class member who actually suffered the injury, several issues can pose as a barrier to the collection of damages. As pointed out before, there is a problem with incentives, once the costs can be higher than the expected benefits (especially in the small claims class actions).

like an attorney to its associates - hence, they will need a specific authorization to collect the damages on behalf of these people and will have to prove they are class members in order to avoid the need for individual enforcement.

72 GYLES, Myriam; FRIEDMAN, Gary B., supra note 30, at 106-8.

73 Depending of the activity branch of the defendant, the regulatory authorities may command them to make provisions on possible losses in lawsuit. These provisions will be considered for accountability purposes. Regarding banks, these rules are settled in the provisions issued by the Brazilian Central Bank, such as the Bulletin n. 019217/2009. 
There is also a difficulty when it comes to information, once these judgments are rarely publicized in a way the class members will have access to it. As much as the National Council of Justice determined the creation of a database with information about all class actions judgments and settlements in it's website - and the public prosecutors' offices of some states already did that - it is doubtful that a common citizen will access these media channels. The ones who could be the intermediary between these information and the class members would be the lawyers, intending to communicate the existence of a class action to the class member in order to represent him in the enforcement phase. Nonetheless, there are very restrictive ethical rules in the Lawyer's Code (Act n. 8.906/1994) and in the Ethics and Discipline Code of Brazilian of Brazilian BAR Association that classifies the activities of raising the possibility of a lawsuit without being consulted previously by the client, as well as the advertisement of ongoing lawsuits, as violations punishable with reprimand, suspension and even disbarment ${ }^{74}$. This institutions design of Brazilian BAR Association aims to prevent the creation of an "entrepreneurial bar"75 - a strategy that may avoid ethical discussions, but certainly impacts on the effectiveness of the class action system.

Considering these factors, apart from cases with great visibility in the media, it is expectable that few class members will enforce the judgment individually. The legislator probably considered this hypothesis and, to uphold the deterrence effect of the class actions for damages, came up with the possibility of a "collective enforcement" to be filed by one of the class actions standing holders in cases where the number of class members collecting damages individually is too low ${ }^{76}$.

This strategy, although well intentioned, also face some barriers. One of them is informative. The law poses that any class action standing holder can file the collective enforcement of a class action judgment - it does not have to be the same entity that originally filed the lawsuit. This aims to increase the chances of having a collective enforcement, but the lack of communication between these entities can make it more difficult, insulating the enforcement to the same entity that filled the class action in the first place. Even in this case, as the class actions generally take a long time to reach a final judgment ${ }^{77}$, the prosecutors, public attorneys and even associations' member assigned to conduct the case may change a lot during this time. Associating this factor with the

${ }^{74}$ Article 34 of the Lawyer's Code - It can be deemed as disciplinary violation: IV - raise the possibility or collect a cause with our without the intervention of a third-party; XIII - publicize legal claims or matters related to pending lawsuits.

$75 \mathrm{GIDI}$, Antonio, supra note 51, at 320.

76 Article 100 of the Consumer Protection Code.

77 The average time for a lawsuit to reach a final judgment is eight years, according to the research conduct by the Brazilian Research Institute for Applied Economics (IPEA), available at http://www.ipea.gov.br/portal/images/stories/PDFs/comunicado/110331_comunicadoipea83.pdf. 
workload these standing holders cope with, there is a risk that the class action outcome just falls into oblivion.

Other barrier that can be envisioned is created by the vagueness of the text of the article 103 of the Consumer Protection Code, which does not establish criteria to what would be considered a fair amount for collective damages, leaving to the Courts to verify it in each case, considering the proportion of the damage. Of course, the discretion of the Court would be in place in any phase of the procedure. However, delaying it to the enforcement phase gives the defendants the opportunity to fight all over again, not about the liability - which has been determined in the first phase - but about the amount asked by the enforcing entity and eventually endorsed by the judge, creating a whole new round of defenses and appeals.

In each one of the hypotheses, either the individual enforcement or the collective one, there is no immediate deterrence effect once the amount of damages will always be conditioned to further actions by the plaintiffs' side. In the absence of an injunctive measure required by the plaintiffs and granted by the Court, the defendant can play the odds and continuing to engage in the harmful practice, hoping that the enforcement phase will happen in a distant future, if it ever happens. They can also make a cost benefit analysis and conclude that the benefits they will gather until the enforcement phase starts (if ever) will surpass the costs they will eventually have to internalize.

For these reasons, the Brazilian system is not efficient in inducing deterrence through class actions for damages, especially when it comes to small claims.

\subsubsection{Does it generate other positive externalities?}

As discussed in the beginning of this chapter, William Rubenstein developed the idea that small claims class actions should be fostered not only because of possible compensation and the deterrence effect - both extensively praised by American legal scholars - but also because this kind of litigation generates other positive externalities, namely: (i) setting precedents, creating scale economy in the judgment of future cases; (ii) creating a range of settlement, inducing litigants to end the dispute before trial and (iii) reduce social costs by transferring part of the costs of enforcement for private parties.

Considering the described structure of Brazilian class actions for damages - and the Brazilian legal system as a whole - these positive outcomes are not so enhanced. However, some new legislation may change this scenario - or, at least, part of it.

The first aspect that must be discussed is the stare decisis rule - once it is the one suffering a considerable transformation at this time. Until the enactment of the reformed 
Brazilian Rules of Civil Procedure (Act n. 13.105/2015) ${ }^{78}$, as a rule the Brazilian legal system did adopted stare decisis model, so the judges were not bound by the result of any other cases - even identical ones that were judged by the state Courts of Appeal or by the Superior Courts ${ }^{79}$. This was a result of the one of the basic principles of Brazilian procedural law, the principle of the independence of the judges. According to this principle, the judge has the right and the duty to decide the case before him free from external pressures and even from parameters fixed in other judgments, adopting the view that "each case is a different case".

Brazilian legislation has been altering this general rule within time. As a matter of fact, the Brazilian legal system admits binding precedents in specific cases, at least ever since the Constitutional Amendment n.3, enacted in 1993. This amendment included in the Constitution the power for the Supreme Court to declare the constitutionality or unconstitutionality of laws, challenged directly in the Supreme Court - therefore, appreciating cases that were never judged by inferior Courts ${ }^{80}$. The judgment rendered by the Supreme Court in these cases are binding precedents and must be applied by all Brazilian Courts, by the Government and its entities and, ultimately, be observed by the legislator in the enactment of rules in the future.

Another step towards a robust precedent system occurred in 2004, after new amendment to the Brazilian Constitution, that mad possible for other judgments rendered by the Supreme Court to become binding precedents - not limited to the ones discussing the constitutionality of laws.

Most Brazilian legal scholars considered these steps a significant evolution, once the allow a more efficient solution of new cases, as well as promote consistency in the judgments rendered by different Courts all around the Country ${ }^{81}$.

Nevertheless, the existence of these rules cannot be confused with a structured stare decisis system. It is important to point out that, before the enactment of the new

\footnotetext{
${ }^{78} \mathrm{~A}$ significant reform of the Brazilian Rules of Civil Procedure took place in the last years and will become enforceable in March 16, 2016. The reformed text keeps the essence of the former code, but tries to bring more agility to the procedures and increase the coherence of the system. One of the measures to do so, as we will further explore, is the expansion of the binding precedent rules.

79 The Brazilian court system is integrated by (i) trial Courts, which first analyze, conduct discovery and decide the matters of law and fact; (ii) appellate Courts, which revises the legal matters of the decisions from the trial Courts of the whole state; (iii) Superior Court of Justice, which revises the decisions from the appellate Courts regarding the compliance to federal law or to resolve splits among appellate Courts; (iv) Supreme Court, which decides constitutional matters.

${ }^{80}$ Article 102, I, "a" of Brazilian Constitution - the Supreme Court will, originally, entertain and judge lawsuits challenging the constitutionality of federal or state law.

${ }^{81}$ Most of legal scholars agree that the adoption of a system that allows binding precedents brings a number of benefits like increasing efficiency and decreasing inconsistencies, as well as the workload of lower Courts. See MENDES FERREIRA, Gilmar, Passado e Futuro da Súmula Vinculante: considerações à luz da Emenda Constitucional n 45/04, in: Reforma do Judiciário, 2005, p-353. See also TAVARES, André Ramos. A Súmula Vinculante na Emenda Constitucional n ${ }^{\circ} 45 / 04$ in Reforma do Poder Judiciário no Brasil Pós-88, São Paulo: Saraiva, 2005, p-122.
} 
Civil Procedure Code, only a few judgments rendered by the Supreme Court, about constitutionality of laws and the ones that are appreciated by the Justices in a different and more formal procedure - including a vote for a qualified majority of $2 / 3$-, can become binding precedents ${ }^{82}$. Besides the more stringent procedure, the binding precedents are restricted to resolve matters of law - especially regarding its interpretation towards Constitution - focusing in barring the proliferation of identical lawsuits discussing the same legal aspects ${ }^{83}$. On the other hand, the stare decisis, by definition, works with the concept of identical cases in factual basis.

Taking into account that a considerable part of the small claims class actions involve disputed facts, only a small percentage of them - or, at least, only certain aspects of this sort of lawsuit - would qualify to become a binding precedent in the current Brazilian legal frame of binding precedents. Although previous decisions from appellate Courts can and do provide guidance for the judges, there are no collateral stoppel rules to avoid the re-litigation of factual issues, and even the legal framing of the facts would be free most of the times.

The rules for binding precedents proposed by the new Civil Procedure Code, which will come into effect in March 2016, try to solve this issue through a series of measures. It commanded all Courts to "make uniform their jurisprudence and keep it stable, wholesome and coherent" ${ }^{\prime 4}$ by creating a database with all binding decisions and statements of the predominant understanding of the Court ${ }^{85}$. These binding decision and statements will observe and take into account the factual panorama of the case (or cases) that originated the discussion ${ }^{86}$. This is important, so the judges are able to analyze if a

\footnotetext{
82 According to the Article 103-A of the Brazilian Constitution, the Supreme Court can choose cases, sua sponte or by request of the parties, and after the decision by $2 / 3$ of the Justices, determine that the decision will bind all the judiciary branch, as well as public administration as a whole.

83 The constitutional provision itself mentions the goal of barring the proliferation of lawsuits discussing the same legal matter (Article 103-A, $\S 1$ o of the Brazilian Constitution). One of the consequences of this provision was the enactment of a rule, that integrated the Rules of Civil Procedure in 2006, which allows the judge to refuse to entertain a claim that discusses only legal matters and that is being decided in other cases against the plaintiff (Article 285-A of the Brazilian Rules of Civil Procedure).

${ }^{84}$ Article 926 of the reformed Brazilian Rules of Civil Procedure - The Courts must keep their jurisprudence uniform, stable, wholesome and coherent.

${ }^{85}$ Article 926, $\S 10$ of the reformed Brazilian Rules of Civil Procedure - As stablish in the Courts bylaws, the Courts shall edit a summary of their judgement, containing the predominant understanding of the Court.

Article 927, §50 of the reformed Brazilian Rules of Civil Procedure - The Courts will make their precedents and jurisprudence public, organizing them by subject matter, preferentially through the world wide web.

${ }^{86}$ Article 926, §2ㅇ of the reformed Brazilian Rules of Civil Procedure - In the edition of a binding precedent, the Courts shall observe the factual circumstances of the case, which led to the creation of the precedent.
} 
certain case falls into the same factual pattern or not and justify the applicability of the precedent, which they are, by the same new Civil Procedure Code, obliged to do ${ }^{87}$.

The new rule on binding precedents in Brazil also compile and expand the list of binding decisions rendered by the Supreme Court and Federal Superior Court, pointing out the obligation for the inferior Courts to apply them when judging identical cases ${ }^{88}$.

It is not yet possible to know how the system introduced by the new Civil Procedure Code will be applied by Brazilian Courts - especially because it does not expressly commands trial Courts to apply appellate Courts precedents (as it does regarding the Supreme Court's precedents). But the fact that it brings the factual patterns of the cases to the center analysis of precedents, points in the direction of a stare decisis systems, in which the positive externality of creating scale economy in the judgment of future class actions - and even for individual cases - would be among the benefits of small claims class actions in Brazil.

Nonetheless, the reform in binding precedent system must be followed by changes in the class action system - particularly regarding the res judicata in class actions. Nowadays, there is no res judicata in the class action if the plaintiff does not meet the burden of proof.

From the plaintiffs' perspective, under the new rules proposed by the reformed Civil Procedure Code, they would be able to predict the outcome of the lawsuit, if a similar case was already litigated and set a precedent. However, from the defendant's perspective, there is still a significant load of uncertainty, once the res judicata for the defendant does not grant global peace. If the case is judged for the defendant because the plaintiff was not able to meet the burden of proof, the same lawsuit can be filed again (over and over again). Moreover, the judgment for the defendants in a class action for damages does not stop individual lawsuits from other class members, once there is no opt in or opt out requirements ${ }^{89}$.

In other words, even with new rules for setting and applying precedents, the Brazilian class action still does not provide "global peace" for the litigants - especially for the defendant - once lack of stability in the res judicata re-inserts in the equation the uncertainty the new Civil Procedure Code is trying to avoid.

The second aspect that must be analyzed is the creation of a settlement range also described as one of the positive externalities of the small claims class actions in the United States. This happens because, even if no precedents are created in settlements,

${ }^{87}$ Article $489, \S 1$,,$V$ of the reformed Brazilian Rules of Civil Procedure - The decision rendered by the Court will not be considered duly motivated if the Courts simply quotes a precedent, without identifying why this precedent is applicable to the case and demonstrating it.

${ }^{88}$ Article 927 of the reformed Brazilian Rules of Civil Procedure - The Courts must observe [...].

$89 \mathrm{GIDI}$, Antonio, supra note 51 at 343. 
the information about the terms of the agreement would circulate among litigants and influence future settlements. Due to the standing model of Brazilian class action system, the settlements are possible, but are quite different.

All of the standing holders are acting as plaintiffs in a class action on behalf of other people interests - the class members. In this capacity, they cannot settle regarding the substantive right itself or waive on the right class members have to pursue it. Moreover, they cannot settle to collect damages on behalf of the class members ${ }^{90}$. Because of that, most of the settlements are focused on injunctive reliefs, aiming to adjust the policies and the practices of defendants or prospect defendants ${ }^{91}$. Hence, these special kinds of settlements receive a specific name, "Commitment to Conduct Adjustment" (Termo de Ajustamento de Conduta, or TAC, in Portuguese).

It is important to mention the prospect defendants here, once most of the settlements are made before the lawsuit is filed, after an inquisitorial procedure conducted exclusively by the office of the Attorney General, were the public entity investigates the practices of some company to verify their possible harmful effects. The company is summoned to provide explanations and discuss the possibility of settlement, but there is no need to comply with the Due Process clause in this procedure ${ }^{92}$. Considering that most settlements are reached in this phase, and that only the office of the Attorney General can conduct these investigations, it is intuitive that the great majority of settlements are made by this public entity - although all of the public entities that have standing to file the class action can, also, settle ${ }^{93}$.

As said above, the content of the settlement will be injunctive, and the monetary expression is limited to the penalty for default on the commitment regarding the change of policy agreed between the parties. When it comes to small claims, the settlements generally refer to the harmful practices and command changes, such as, stop charging a

90 The logic is that if the decision in a class action for damages will have as an outcome a mere declaratory command, allocating the liability by nonspecific as to the value of the damages, the settlement can not extrapolate the limits of what would be a final judgment in the class action. Nevertheless, the class member can individually enforce the settlement in case of default from the defendant's part. See LEONEL, Ricardo de Barros. Manual do Processo Coletivo. 2. ed. São Paulo: RT, 2011, p-98. See also GRINOVER, Ada Pellegrini; WATANABE, Kazuo; NERY JUNIOR, Nelson. Código Brasileiro de Defesa do Consumidor comentado pelos autores do anteprojeto. vol II. 10. ed. Rio de Janeiro: Forense, 2011.

91 Prospect defendants understood as the ones who engage in the same tortious/harmful conduct comprised by the settlement, and who might be sued by that. We consider they can be influenced by the content of the settlement, and the changes agreed by their peers, even if they did not really participated as a party in the agreement.

92 The inquisitorial procedure that aims to investigate the activities of potential defendants in the civil jurisdiction was inspired by the investigative procedures made by the office of the Attorney General in the criminal procedures, before filing the criminal lawsuit. Because of this inquisitorial vocation, the procedure can only be conducted by the office of the Attorney General, mimicking the criminal law. See MAZZILLI, Hugo Nigro. O inquérito civil, São Paulo: Editora Saraiva, 1999.

${ }_{93}$ Article $5^{\circ}, \S 6^{\circ}$ of the Civil Public Action Act. 
particular fee considered abusive, and establishes a penalty for every time there is a complaint about the same matter.

For example, if a bank agreed on not charging a fee and, after the settlement, consumer complaints to the office of the Attorney General that this fee are charged, the bank will have to pay a fine for the default. The idea is that the amount of the fine is sufficient to deter the behavior but, in case of default, the fines will be collected to the aforementioned public fund, and will not be reverted to the class member who suffered the injury. If the class member wants the settlement to provide him individual compensation, he will have to file an enforcement lawsuit, based on the settlement made by one of the class action standing holders. Once again, the problem of the incentive to file a lawsuit when the benefit will be so small comes to the table.

Considering this scenario, the positive externality of creating a settlement range by promoting the sharing of information between the parties of one dispute and even for future plaintiffs, that could discuss the same issue in the future, is not quite the same as in the United States. The National Council of Justice attempted to fill these informative gaps, by creating of a database for the standing holders - particularly the office of the Attorney General - of different states, to inform the kind of issue that is being settled, and the amount of fines established for default, especially after the requirement broad publicity to either settlements and judgments in class actions ${ }^{94}$. Nevertheless, there is no direct effect on the class members, once the result of the settlement will not provide them with any leverage to settle his case regarding individual damages.

Finally, it is worth mention the positive externality of sharing costs of enforcement between the government - which enforces policies through regulation - and private parties, plaintiffs and defendants - enforcing it through litigation and bearing its costs. Considering the choice of preferred plaintiffs, the exception of costs to file class actions, as well as the rate of collective enforcement and allocation of resources collected to the public funds, it is clear that the government absorbs practically all the costs of class action litigation in Brazil.

In the United States, as all the costs of litigation are transferred to the parties - the payment of attorney's fees, expert witnesses, discovery procedures - the public cost of litigation can be summarized on the maintenance of Courts to entertain the lawsuits, and

${ }^{94}$ The National Council of Justice (CNJ) - responsible for oversee the activities of Brazilian Courts, as well as conduct researches in order to propose changes and enhance the efficiency of the judicial system - issued a rule in 2011, commanding the creation of a database with all class actions and collective settlements, including its themes. One of the goals of this database is to give publicity to these procedures and decisions, allowing the class members to join them or individually enforce the decisions when the time comes. See Joint Resolution n.2 CNJ, available at http://www.cnj.jus.br/atos-administrativos/atos-da-presidencia/567-resolucoes-conjuntas/14836resolucao-conjunta-n-2-de-21-de-junho-de-2011. 
this will be the cost of private enforcement to be compared to the cost of public enforcement. On the other hand, in the Brazilian class action system, not only the costs of entertaining the lawsuit - keep the Courts running, paying the judges, clerks and other staff members - are paid by the government, but also the costs that would be supported by the parties in an individual lawsuit.

The plaintiffs are, with exception of the civil associations, public attorneys or members of the office of the Attorney General. In this capacity, they have all the considerable independence towards the government but, ultimately, the public coffers pay their wages. So, instead of having the plaintiffs' attorneys paid by attorney's fees - a part of what was recovered in the class action - you have in more than $70 \%$ of class actions in Brazil a plaintiff connected to the government ${ }^{95}$, paid by the government and acting motivated for institutional duties ${ }^{96}$.

Moreover, regarding the other procedural fees, paid by the parties to the state to cover part of the litigation costs and other procedural matters - like the expert fees - the plaintiff is exempted of them all, meaning that to begin the lawsuit, the plaintiff will not have to pay the initial costs, he will not have to pay for the cost of any discovery procedure he deems as useful to the case and, if he loses at trial state, he will not have to pay for costs to appeal to appellate Courts or pay for the defendants attorneys' fees. All of these costs (except for the attorneys' fees) are funded by public sources ${ }^{97}$. It is worth to note that only the plaintiffs in class actions benefit from these exceptions of costs - the defendants will have to pay for their costs. These rules create distorted incentives for judges to allocate the costs on the defendant side, uneven the procedural balance towards the plaintiff side.

\footnotetext{
95 The Attorney General's offices in Brazil are the main class representative, as the empirical research conducted by the research group CEBEPEJ, available at http://www.cebepej.org.br/pdf/acoes_coletivas.pdf.

96 The article 129 of the Brazilian Constitution sets under the institutional duties of the office of the Attorney General the duty to conduct the civil investigation and to file the proper lawsuits to protect diffuses and collective rights. Besides the institutional duty, there are also reputational rewards for these public officials when filing class actions on behalf of the whole society - especially when it comes to small claims, which would not, made to the Courts otherwise. Some American scholars discuss the "reputational rewards" for the public officials as plaintiffs in aggregate litigation. See LEMOS, Margareth H.; MINZNER, Max. For-Profit public enforcement, Harvard Law Review, n. 127, 2014, p-854. In Brazil, a research conducted by Getulio Vargas Fundation in 2011 asserted the Attorney General's offices and the prosecutors' offices as the third most reliable public institution in the country. Available at http://mp-ma.jusbrasil.com.br/noticias/3024783/ministerio-publico-e-a-3instituicao-mais-confiavel-do-pais-aponta-fgv .

${ }^{97}$ Considering that Brazil adopts the fee-shifting rule for attorneys' fees, and that plaintiffs in class actions are exempt of all costs, if the judgment is entered against the plaintiffs, the defendant's attorneys will not receive fees. The government does not pay for the attorney's fees, and the defendant's attorneys generally try to correct this distortion by charging higher contractual fees from their clients.
} 
There is a research gap in Brazil regarding the aggregate costs of a common lawsuit and of a class action. Some research conducted by the National Council of Justice focused on the amount of procedural costs a party has to bear in different states - but have not discussed the aggregate costs of keeping the Courts structure ${ }^{98}$. The most comprehensive research on the topic was made by IPEA and the results were released in 2011, concluding that a lawsuit in which the government tries to collect taxes and other debts from taxpayers takes about 8 years to reach a definitive judgment and costs the Treasure, on average, $\mathrm{R} \$ 4,368.00$ (at about US\$2,000.00) ) $^{99}$.

It is not possible, at this stage, to estimate how much the government would pay to for a single class action, but it is possible to imagine that the amount would not be lower than the one found in the research above. Especially considering that besides paying for the costs of keep the Courts working and paying for staff it will also absorb costs of one of the parties - paying the wages of public attorneys and the attorney's generals offices and paying for the procedural costs of the plaintiffs side - even the private ones (civil associations).

Considering these factors, the procedural costs that are privately absorbed are just a small percentage of the aggregate costs of a lawsuit - the part paid by defendant. All the costs of filing the suit, the wages of the plaintiffs' attorneys (which replaces the plaintiffs attorney's fees) - are socially divided. Because of that, the benefit of transfer part of the costs of policy enforcement to private parties practically does not exist. Truth be told, it is doubtful that most class actions in Brazil can be even classified as private enforcement, as it is structured today.

The analysis to whether foster or restrains litigation goes through a verification to what are the social costs of entertaining a lawsuit compared to the costs of enforcing a policy in the administrative sphere ${ }^{100}$. Due to the lack of data, it is not possible to determine if the enforcement through the small claims class action is ultimately cheaper than public enforcement of policies aiming to avoid damages to consumers, investors and other classes subjected to this kind of harm ${ }^{101}$. However, it is possible to say that the

98 The preliminary data on the study are available at http://www.cnj.jus.br/imprensa/433informacoes-para/imprensa/artigos/13592-as-custas-judiciais-em-foco.

99 IPEA, supra note 36.

100 SHAVELL, Steven. supra note 9.

101 Such enforcement is generally made by the regulatory agencies through supervision of the activities, conduction of administrative procedures and the application of penalties (such as fines). Some examples of Brazilian regulatory agencies are the Central Bank, National Monetary Council (CMN) and Monetary Values (Securities) Commission - regarding banking activity and capital markets. The regulatory power of these entities also has the scope of protecting consumers and investors, as a way to create a fairer market. See the description of financial and capital markets regulators of São Paulo Stock Exchange (BOVESPA) available at: http://www.bmfbovespa.com.br/bancobmfbovespa/nonresident/en-us/regulatory-bodies.asp. 
positive externality of sharing the costs of enforcement between public and private agents is severely mitigated in the Brazilian system as it is.

\section{Legislative proposals to deal with Brazilian class actions'} shortcomings

Considering the arguments developed to this point, several characteristics of Brazilian class actions' for damages still fall short when it comes to induce deterrence and promote other positive externalities to the society, especially regarding small claims. Although the American system also has very contentious issues surrounding the same kind of lawsuit, as discussed above, one ca say that Brazilian legislators should inspire themselves on the United States experience to make the small claims class actions more socially beneficial.

That certainly does not mean to import the American rules with no critical thought ${ }^{102}$. The following ideas for legislative adjustments try to incorporate some of the positive aspects of American's class actions to the Brazilian system with a minimum level of disruption. The proposals exposed here concern specifically the creation of a system to entertain small claims through class actions, with greater social and individual gains. As much as the problems exposed in the third chapter, to a certain extent, reach all of the class action for damages, this paper chose to target the ones in which the class members would not have enough incentive to pursue the damages individually. A legislative change reaching all possible class actions for damages would demand a more comprehensive and profound reform of the system as a whole.

\subsection{Deterrence}

In my opinion, the most critical point to address is the deterrence effect of class actions for damages. As said before, the Brazilian system is poorly provided with deterrence mechanisms, once the defendant can, virtually, bet on a future and uncertain enforcement phase that will actually determine the amount of damages he will have to pay. A fragile notice procedure and a prohibitive set of rules to keep lawyers to pool and enforce the small claims class action judgment, allows the injurer to count with a low level of deterrence, if any. That happens because the Brazilian system is primarily focused on

102 The plain reproduction of American legal system would be faded to fail in Brazil, once it is country from the Civil law family and intrinsically influenced by the European systems (particularly the Italian system when it comes to civil procedure). I believe that has to do with the fact that Brazil had a much more strong and continuous cultural and academic interchange with Europe than with the United States. This tends to change within time, once the new generations of legal scholars are consistently seeking legal education in the U.S. See FERNANDES, Débora Chaves Martines, supra note 53 , at $30-31$. 
compensation, so much that punitive damages are not expressly addressed in any statute $^{103}$. To bring deterrence to the center of the discussion - where it belongs, especially in the small claims field -, and effectively promote policy changes to avoid mass torts, some legislative changes are required.

The first one has to do with the immediate perception of loss by the injurer, meaning that, once the liability is established, the losing defendant must have a dimension of the damages he will have to pay - what does not happen in the current system. To do so, the legislator should change the provisions of the Article 95 of the Brazilian Consumer Protection Code, to determine that the decision in the class action for damages will not be generic any more. The judgment will have to establish a certain amount of damages, even if this amount is based on an estimative drafted by the judge.

To withdraw the generic character of the class action decision would require another set of changes to make possible the discussion of the amount, complying with the Due Process rule ${ }^{104}$. To allow the judge to estimate the value of the damages, the parties would have to engage actively in the identification of the class, from the pleading phase on.

Today, the rules allow the plaintiffs to formulate a generic plea to assert the liability of the defendant injure ${ }^{105}$. This pleading standard would have to be changed, and the plaintiff would have to try to delimitate the class members, as well as prospective value for the individual injure. The Attorney General's office would accomplish this goal easier than other standing holders, once they can use the inquisitorial procedure prior to the filing of the class action to collect information in order to determine the individual and the aggregate amount of damages ${ }^{106}$.

The fact that the amount of damages will be actually a controversial matter in the first phase of the class action, as well as part of the decision, would incentivize the

103 The conclusion that the enforcement of liability rules is limited to the compensation for the damages (in its' exact extension) comes from the interpretation of the Article 927 of the Civil Code, which states that one who commit a tortious act and cause damages by doing so must repair it. Nevertheless, in several points of different statutes, the idea of fixing damages to achieve a purpose of deterrence is clearly present. One of the example is the Article 100 of the Consumer Protection Code which, as discussed above, allows the standing holders of the class actions to collect the damages in a collective fashion, even if they didn't suffered the damage caused by the losing defendant. On other examples of this issue, see SERPA, Pedro Ricardo, Indenização Punitiva, unpublished masters' degree dissertation; University of São Paulo (Brazil) - 2011, available at http://www.teses.usp.br/teses/disponiveis/2/2131/tde-15052012-102822/pt-br.php.

104 The procedural Due Process requirement would only be granted by a change in the rules of disclosure and discovery. Here, these measures would involve commanding the parties to engage in efforts to achieve the most precise aggregate amount of damages. About discovery procedure and due process in Brazil, see: MARINONI, Luiz Guilherme; ARENHART, Sérgio Cruz. Prova, 2ªed, São Paulo: Saraiva, 2014.

105 Once the only decision possible is a generic command asserting the liability, as prescribed by the Article 95 of the Consumer Protection Code.

${ }^{106}$ As discussed above on pages 33 and 34 of this paper. 
defendant to come forward and actively disclose information about the possible members of the class - in order to try to diminish or constrain the damage amount. In the current system, as the class members have to come forward by themselves and only in the enforcement phase - which, sometimes, can take more than five year to be initiated -, the defendants have all the incentives to conceal all the information they have about the class members and about the amount of damages. Changing these rules would make the discovery phase of the class action for damages richer in terms of information shared by the parties and more effective, once the discussion about the amount of the damages including criteria to calculate them - would be made in an aggregated way, saving costs to the class members and to the defendant ${ }^{107}$.

The judge will have to summarize, in his decision, the discussion over the amount of damages developed in the discovery phase, carefully stating the criteria used to fixate the amount, eventually referring to expert witnesses' testimonies if necessary. The idea is to exhaust the discussion on the amount of damages in the first phase of the class action, granting the opportunity for the defendant to appeal to the higher Courts both regarding the aggregate amount of damages and the criteria to calculate them. This would avoid the inefficiency of having to discuss the amount of damages in each one of the individual enforcement procedures, as well as the criteria do calculate them, having access to the appellate Courts in each one of these procedures - eliminating the severe workload appellate Courts have to cope with in the current system ${ }^{108}$.

An immediate perception of the damage would enhance the deterrence effect, but to induce policy changes to avoid similar injuries - not only for the defendant but also for other companies in the same market - the injurer should be compelled to internalize the costs immediately too. In other words, the money should leave the defendants coffers right after a decision asserting his liability. As said before, the average time for a final decision in a Brazilian civil court is eight years and most appeals, as a rule, stay the enforcement of the decision under discussion. Therefore, the way to make the injurer

107 Once the evidences necessary to access the dollar amount of the damages would be made in an aggregate fashion and not in each individual enforcement lawsuit - in which both parties would have to engage in discovery activities.

108 In each of the individual enforcement procedures there is the opportunity for the parties to take the decision to the appellate court for review. The enforcement phase of a class action can follow different paths: (i) if the assessment of the damage amount in the individual case depends on discovery not made in the first phase (Articles 475-A, 475-C and 475-E of the Brazilian Rules of Civil Procedure) and (ii) if the assessment of the damage amount depends only on arithmetic calculations (Articles 475-B and 475-J of the Brazilian Rules of Civil Procedure). In the first scenario, there may be at least two appeals - one interlocutory and one final appeal (Articles 475-H and 475-M, $\S 3^{\circ}$ of the Brazilian Rules of Civil Procedure). In the second scenario, there may be at least one final appeal (Article $475-\mathrm{M}, \S 3^{\circ}$ of the Brazilian Rules of Civil Procedure). Considering that a determinate class may have thousands of members, the appellate Courts may have to absorb an overwhelming number of appeals related to the enforcement of the same class action's decision. 
internalize the costs immediately is to change the Article 520 of the current Brazilian Rules of Civil Procedure, which talks about the stay rules for appeals ${ }^{109}$. The statute already contemplates a series of exceptions to the general rule of stay ${ }^{110}$ and the decision in class actions should be included among these exceptions if the goal is to enhance the deterrence effect. Moreover, solely the alteration of the rule that allows a generic decision to a rule that commands the payment of a certain amount should incentivize the losing defendant to make a deposit on a fund with the same interest rates of judicial decision, which are way higher than most of the low risk investments ${ }^{111}$. Unfortunately, the new Civil Procedure Code did not address this aspect and kept the automatic stay rule as it is today ${ }^{112}$.

Once the decision is not yet definitive, the amount should be deposit in a fund and do not be awarded to any of the class members before a final decision from the appellate and superior Courts affirming not only the liability, but also the amount of damages. The judge would be responsible for the administration of the fund or the account in which the money shall wait for the final decision, and here no changes would be required, because this is the current rule for all civil lawsuits in Brazil ${ }^{113}$. This would conserve part of the procedure that exists nowadays, in which the class members will direct their pleas to

109 The stay rule suspends the effects of the decision while an eventual appeal pending of judgement.

110 The exceptions to the general rule of automatic stay of the trial court decisions are listed in the sections of Article 520 of the Brazilian Rules of Civil Procedure. The automatic stay doesn't apply to the following decisions: (i) the one that establishes or ratify land demarcation; (ii) the one that establishes or fix the amount of child support; (iii) the one that decides a preparatory procedure; (iv) the one that decides the losing part response in the enforcement phase of any procedure; $(v)$ the one that commands the remittance of the procedure to an arbitration panel and (vi) the one that confirms a previous decision grating a urgent measurement. Although in these cases the stay of the trial decision in not automatic, the judge may stay it if the party suffering the effects of the decision demonstrates that it will imply in excessive hardship or submit her to risk of losses that will be hard to compensate in the future.

${ }^{111}$ According to a recent decision from the Superior Tribunal of Justice, the Brazilian superior court responsible for deciding issues related to federal law, the debts that result from judicial decrees must be update by the interest rate applied to the credits of the treasury. Today, this index is called SELIC and varies daily (rate variation available at the Central Bank website, at http://www.bcb.gov.br/htms/selic/selicdia.asp). It totals, in average, 10 to $12 \%$ per year. Considering these data, and the fact that a low risk investment would repays approximately half of this interest rate (savings account or a low risk investment cost), the incentive to make a deposit in a fund under the administration of the judge to elicit the monetary actualization using the SELIC criteria is considerably high.

112 Article 1.021 of the Reformed Brazilian Rules of Civil Procedure - The appeal will stay the effects of the judgement.

${ }^{113}$ According to the Article 139 of the Brazilian Rules of Civil Procedure, the judge has the assistance of people or entities to accomplish its duties. One of these assistants are the trustees, to whom the property dispossessed by judicial decisions are trusted until the rendering of a final decision about the rights over it. Regarding money amounts the trustees are banks that make agreements with Courts to keep and administer the funds containing money figures paid to comply with judicial decrees. The federal Courts have a general agreement with the public federal bank (Caixa Econômica Federal) and each of the state Courts have its' own agreement - generally with public banks. 
collect the damages to the court and not, for example, to the plaintiff of the initial phase of the class action.

\subsection{Compensation}

To incentivize class members to apply for receiving the damages they were awarded by the class action decision, the idea would be lowering the costs people actually bear in the enforcement phase, such as court's fees and attorneys' fees. If the discussion on the liability and on the amount and criteria to calculate the damages were anticipated to the first phase of the class action - as suggested above - there would be no critical point to discuss individually. Moreover, there would be no legal matter left to debate. That would make possible to simplify the procedure, reducing it to a form to be filed by the class member, along with documental evidence proving class membership. In the absence of debatable legal issues, the attorney's presence could be waived by the party, which is done in some instances of Brazilian judicial system but not specifically in the class action system ${ }^{114}$.

If all of these suggestions were to be adopted, the express provision authorizing the judicial control of the adequacy of representation would be imperative. Today, there is an assumption that the statutory established standing holders adequately represent the interests of the class, dispensing the judicial control of this requirement. In my opinion, this rule should be included in the system regardless of any other substantial change, as a way to grant the paramount rule of Due Process of Law in a scenario were rights and interests of absent people are being discussed. But if substantial part of the discovery, specially concerning the amount of damages, were to be conducted by the class representatives and not anymore by the class member himself in the enforcement phase, the adequacy of this representative should be submitted by an ongoing evaluation by the court, throughout the procedure ${ }^{115}$.

114 Two examples are: (i) the small claims Courts (Act n. 9.099/1995), in which people don't need to be represented by lawyers in claims up to 20 times the minimum wages (today it totals $R \$$ $15,760.00$, approximately US\$ 5,200.00); (ii) in the procedures in labor Courts (except in the Supreme Labor Court) neither the plaintiff nor the defendant need to be assisted by lawyers (Article 791 of the Consolidation of Labor Law).

115 As mentioned above (page 22) one of the mechanisms the Brazilian system adopted to grant the adequacy of representation was to submit the plaintiffs to an external control by the office of the Attorney General - whenever this entity is not the plaintiff itself. It is called the capacity of custus legis. The problem with this rationality is that it assumes that the office of the Attorney General is adequate representative in each and any case, and that it will actually exercise the custus legis function properly, by taking the control over the lawsuit whenever the name plaintiff is not carefully defending the interests of the class. Allowing a ongoing evaluation of the adequacy of representation by the judge would be easier and more effective. See FERNANDES, Débora Chaves Martines, supra note 53 , at 107-114. 
The adoption of such a system would also require a recrudescence of the pleading standards regarding which claims should be treated as a class action for damages and which should not. In Brazil there is no formal certification phase, but the judge still must analyze questions of commonality and typicality ${ }^{116}$ in order to entertain the class claim. Regarding the class actions for damages, these criteria refer to the uniformity of the source of injure and the superiority of the class solution over an individual lawsuit ${ }^{117}$. The commonality requirement would gain more weight in this scenario, reaching to the uniformity of the damage suffered, once this would grant that no individual question extrapolating the common would be left out of the damage amount discussion.

Considering the fact that in the small claims realm the class members have very little or no incentive to bring an individual claim, the rules concerning the res judicata could also be changed, extending the decision to all class members regardless of the result. As stated before, the res judicata in the class action for damages today only bind the class member if the judgment is entered for the class. But in a scenario in which the individual claim would most probable not be litigated, the legislator could make a political option to bind the class to negative judgments too - providing the defendant with "global peace" and ensuring that no other class or individual claim regarding that injure would be entertained. Of course this new rule would have to be preceded by an opt-out opportunity for the class members, as well as with rules regarding the verification of the adequacy of representation $^{118}$.

Either to grant the class member the opportunity to opt-out or to assure that he will come forward to collect the damages, the notice system would have to be improved. The general rule of the Article 94 of the Brazilian Consumer Protection Code, to publish in the Official newspaper the existence of a class action discussing a particular theme would have to be expanded to allow other forms of notice, such as advertisement in greater circulation newspaper, with the costs being absorbed by the losing party ${ }^{119}$.

${ }^{116}$ Commonality and typicality are two of the four prerequisites to certify a lawsuit as a class action. The first entails that there must be questions of law or fact common to the class (Rule 23, a, 2 of the Federal Rules of Civil Procedure) and the later means that the claims or defenses of the representative parties are typical of the claims or defenses of the class (Rule 23, a, 3). If the class representative fails to fulfill these requirements, the class will not be certified and, therefore, there will be no class action.

117 In an analogous way as the commonality and typicality (Rule 23 (a) (2) and (3)). See GRINOVER, Ada Pellegrini. Significado social, político e jurídico da tutela dos interesses difusos. Revista de processo, São Paulo: Editora Revista dos Tribunais, n. 97, jan-mar/2000, p. 9-15.

$118 \mathrm{GIDI}$, Antonio, supra note 51, at 343-44.

119 There would generally apply to the losing defendant and the need to publicize and give notice to the class members about the decision rendered against him, in order to allow people to come forward and enforce the decision. There would be no need to give broad notice of a decision rendered against the class (and, hence, to allocate the costs of the publication to the plaintiffs), once the defendant would be able to use this decree to preclude future litigation when it happens. 
All of these changes would extinguish the need for a provision of collective enforcement of the decision - which were the way of the system to, allegedly, induce deterrence. In the new system, the time limit of one year stated in the Article 100 of the Brazilian Consumer Protection that triggers the possibility of a collective enforcement, would turn to a limit to collect the damages individually, and the surplus in the fund would be reverted to the public fund that already exists. Other solutions can be envisioned, like the donation of the unclaimed surplus to a charitable entity, as it happens in the American model of the cy press class actions ${ }^{120}$.

\subsection{Other positive externalities}

Finally, when it comes to increase other positive externalities, the legislative proposals would have to reach a deeper level of changes in the Brazilian civil procedure. Luckily, the new Civil Procedure Code set in motion some of these changes, broadening the rules for binding precedents in all Brazilian Courts. If well applied, these rules will help to create scale economy and avoid re-litigation based on a system of precedents that would really affect the small claims class actions - once it will decide and include in the precedent the factual aspects of the cases. In a civil law system, this is a dramatic, but welcomed change ${ }^{121}$.

On the other hand, to bring stability to the system, the Brazilian legislator will have to promote changes in the res judicata rules in the small claims class action. To bind all class members to the final judgment and extinguishing the possibility of another standing holder filing the same class action in the future in case the judgment is entered for the defendant, might, at least, preclude the re-litigation of the same factual issues and help to bring the stability the system needs.

Regarding the positive externality related to the creation of a settlement range, not much could be changed without a structural alteration of the notice procedures, the optin/opt-out rules and the verification of the adequacy of representation. As pointed out before, the standing holders cannot settle regarding the amount of damages, they are allowed to make only peripheral concessions with injunctive character, over the manner in

120 REDISH, Martin H.; JULIAN, Peter; ZYONTZ Samantha, supra note 41.

121 The changes would have to be structural because the primary source of the law are the statutes. The case law, or jurisprudence, is considered a secondary source of law and, in this capacity, have value as a repository that can be used by judges to guide their decision making process but has no biding effects. To allow the jurisprudence as a whole to have binding effects a constitutional amendment would be required and, even in this event, there would be discussions about the supreme and inalterable principle of the separation of powers - once the Courts would be engaging in legislative activity (Article 60, $\S 44^{\circ}, \mathrm{III}-$ There will be no deliberation about amendments aiming to abolish the separation of powers). 
which the defendant will adjust its behavior to the law ${ }^{122}$. The creation of a database with the settlements celebrated by the offices of the Attorney General may generate a positive externality of establishing the policy adjustments that are being proposed by the class action standing holders, increasing the efficiency of future settlements and, even, inducing policy changes of possible defendants in similar cases to avoid litigation ${ }^{123}$. Nonetheless, the amount of damages still cannot be object of the settlement, once the system doesn't provide sufficient safeguards for both parts to make it viable.

The only way these could be change would be creating a system similar to the American, in which there is proper notice for the class members - either personal or, if not possible, through wide public announcements ${ }^{124}$-, evidentiary hearing ${ }^{125}$ as to the fixation of the amount of damages, the right to intervene and question the terms of the settlement and, ultimately, the right to opt out ${ }^{126}$. The settlement should them be approved by the court and, following to change proposed for the res judicata rules, the settlement should bind all the class members - otherwise it would be useless ${ }^{127}$. Besides, once again the adequacy of representation - and the need to include a statutory provision that allows the judge to verify this requirement - is a critical point, to grant that the representative is, in fact, acting in the class members' best interest.

At last, the institutional arrangement of Brazilian class action system prioritizes public entities - especially the office of the Attorney General - as a preferable representative for class members. As much as this choice has some positive aspects, such as the existence of a representative with a institutional duty to file this kind of suit therefore virtually immune to variable economic incentives involving the lawsuit -, it impairs the sharing of the enforcement of liability rules with private parties, preventing

122 GIDI, Antonio, supra note 51, at 343. See also VIEIRA, Fernando Grella. A Transação na Esfera da Tutela dos Interesses Difusos e Coletivos: Compromisso de Ajustamento de Conduta, in: Ação Civil Pública: lei 7.347/1985 - 15 anos. MILARÉ, Édis (Coord.). 2. ed. São Paulo: Revista dos Tribunais, 2002, p-220.

${ }^{123}$ As discussed above on pages 34 and 35.

${ }^{124}$ As pointed out by Antonio Gidi, the general rule of the Article 94 of the Consumer Protection Code is mostly ineffective, once no one actually reads the official newspapers, issued by the states and by the federal power. So, as much as the Brazilian law escaped the Eisen v. Carlisle (94 S.Ct. 2140 , No. $73-203,1974)$ problem with notice, it created a too loose standard for notice, which affects the possibility to bind all the class members to the final decision in the class action. See GIDI, Antonio, supra note 51 , at 342 .

125 An evidentiary hearing is a formal examination of charges by the receiving of testimony from interested persons, irrespective of whether oaths are administered, and receiving evidence in support or in defense of specific charges and claims. In this context, we support the evidentiary hearings to grant the parties the right to present evidence of the extension and the amount of damages, to give the Court subsides to decide about this matter.

$126 \mathrm{GIDI}$, Antonio, supra note 51, at 342-43.

127 Id. at 344. 
the innovations that such sharing mechanism could generate ${ }^{128}$. The only way to correct this flaw and keeping the current standing rules $^{129}$ would be creating economic incentives to the civil associations to effectively organize and make a more extensive use of the judicial system to achieve their institutional goals. In a scenario in which the amount of damages is determined in the first phase of the class action, this incentive could be a percentage calculated over the amount of the fund ${ }^{130}$. This would attract more qualified lawyers to the civil associations, systemically improving the defense of class interests from the point of view of an institution that deals daily with the concerns of the class members, what might not be reached by the public enforcers.

Although it may sound repetitive, the Courts' power to verify the adequacy of representation is critical in this point too, once nowadays, without the requirement, many sham associations file class actions, make a poor defense of the class rights, with the solely purpose of collecting attorney's fees. A large number of these associations have never been engaged on the defense of any civil right - they are law firms structured as associations $^{131}$. If the Courts are empowered to control the adequacy of representation and punish this sort of behavior, along with the provision of some incentives to a more structured representation net in the civil society, the private enforcement of liability rules through class actions could become a reality in Brazil.

\section{Conclusion}

To grant that private enforcement of liability rules will reach its full potential, it is imperative to make possible that even claims that are too small to be litigated individually will have ways to get to the Courts. The class actions provide this path and, by doing so, they enhance the deterrence effect over harmful activities, making the injurers internalize the cost of their behavior through the payment of damages. Considering these features, they become an alternative to government regulation (public enforcement) and even to the idea that the free market regulates itself through competition. That happens because

128 THOMPSON, Barton H., The Continuing Innovation of Citizen Enforcement, University of Illinois Law Review, vol. 2000, n.1, 2000.

${ }^{129}$ As discussed in the pages 22 and 23 above.

${ }^{130}$ Analogous to the American rules for attorney's fees, following the procedures of Rule $23(\mathrm{~h})$ of the Federal Rules of Civil Procedure.

131 The main difference of the association and the corporations is that the pursuance of profit can only be a goal for corporations. Associations are non-profit oriented organizations - and they are only ones with standing to file class actions. What happens in the practice is that law firms structure themselves as associations in the paperwork so they can file class actions - acting like plaintiffs and representatives at the same time (most of the times, the attorney's are part of the board of the association), with the goal to collect attorneys' fees. In the end of the day, they are moved by the prospective profit and, because of that, they can't be considered neither associations nor standing holders. See FERNANDES, Débora Chaves Martines, supra note 53 at, 196-205. 
public enforcement may be constrained by lack of resources, by the different priorities among political groups and strong industry lobbies, among others ${ }^{132}$. To this extent, it is safe to say that both the American and the Brazilian class action systems play a very important role on the private enforcement scenario, by enabling aggregate litigation of group claims.

Nevertheless, the Brazilian system seems to be structured to focus on the compensation aspect of the class actions, neglecting the positive externalities this sort of procedure may generate, especially the deterrence effect. In this paper, we asserted that deterrence should be in the center of small claims class action litigation - considering that compensating small losses are less important than avoid the perpetuation of similar potentially harmful activities. In the urge to achieve an individual ideal of justice considering aspects of access to the Courts and individual compensation - the Brazilian class actions legislation and practice fall short in achieving the social welfare that could be an outcome of these special procedures. With these shortcomings in mind, and taking the American class action system as a model for comparison, this paper tried to propose several procedural changes in Brazilian statutes to enhance the social benefits that can be outcomes of small claims class actions.

Considering specifically this kind of class action, most of the proposals focused on increasing the deterrence potential in the enforcement phase, for example, by determining that the class action decision fixes an aggregate amount for damages and commanding immediate payment from the losing defendant. This proposed change aim to make the losing defendant to effectively internalize the costs of his harmful activity in a way that induces him to take an optimal level of care, once this is hardly perceived in the current legal scenario in Brazil.

Although deterrence has been prioritize in this paper, the proposals didn't neglected changes to increase the effectiveness of the damages' recovery by the class members, especially considering that facilitating recovery have positive effects on deterrence as well. In this realm, the paper suggested legislative changes to reduce court bureaucracy and costs, to incentivize even people with low stakes to come forward and collect the damages.

Regarding the possibility to generate other positive externalities such as the decree effects, the creation of settlement ranges and the distribution of costs between private and public enforcers, the paper concluded that structural changes in the Brazilian legal system would be required to achieve these goals - and some of them are already happening. Without changes in the standing rules of class actions, aiming to consolidate

132 HENSLER, Deborah, supra note 6. 
the private entities or persons as law enforcers, and without the enactment of rules that allow prior decisions in class actions to bind latter decisions in lawsuits discussing the same claims, these goals will hardly be achieved.

As a conclusion to this perfunctory analysis, it is possible to say that both American and Brazilian class actions systems have its shortcomings and its strong points when it comes to balance the costs, the benefits and the final goals of this sort of litigation. This paper aimed to add on the ongoing discussions about the topic and to the exchange of ideas and experiences among different legal systems, hoping that it can enrich the debate and create conditions for legislative development and positive changes in the future.

\section{References}

CALABRESI, Guido. The Cost of Accidents: A legal and Economic Analysis, New Haven, Connecticut: Yale University Press, 1970.

CAMPOS. Sergio J., Class Actions All the Way Down, Columbia Law Review, n.113 Sidebar 20, 2013, available at: http://www.comlumbialareview.org/wpcontent/uploads/2013/02_Campos.pdf.

CAPPELLETTI, Mauro; GARTH, Bryant. Access to Justice: A world survey. A. Giuffrè, 1978.

COFFEY JR., John C. The regulation of entrepreneurial litigation: balancing fairness and efficiency in the large class action, University of Chicago Law Review, N.54-3, Summer 1987.

FERNANDES, Débora Chaves Martines. Controle judicial da representatividade adequada das associações civis, unpublished masters' degree dissertation; University of São Paulo (Brazil), 2013.

FRIEDENTHAL, Jack H. et. al., Civil Procedure: Cases and Materials. Eagan, Minnesota: WEST, 2013.

FROMM, Blanc. Bringing Settlement out of the Shadows: Information about Settlement in an Age of Confidentiality, UCLA Law Review, n. 48, 2001.

GIDI, Antonio, Class Actions in Brazil: A Model for Civil Law Countries, 51 University of Houston Public Law and Legal Theory Series, n.51, 2006-A-11.

GRINOVER, Ada Pellegrini. Significado social, político e jurídico da tutela dos interesses difusos. Revista de processo, São Paulo: Editora Revista dos Tribunais, n. 97, p. 9-15, jan$\operatorname{mar} / 2000$.

GRINOVER, Ada Pellegrini; WATANABE, Kazuo; NERY JUNIOR, Nelson. Código Brasileiro de Defesa do Consumidor comentado pelos autores do anteprojeto. vol II. 10. ed. Rio de Janeiro: Forense, 2011.

GYLES, Myriam; FRIEDMAN, Gary B. Exploding class action agency cost myth: the social utility of entrepreneurial lawyers, University of Pennsylvania Law Review N. 155, 20062007. 
HAY, Bruce L. Procedural justice - ex-post v. ex-ante, UCLA Law Review, n.44, 1997.

HENSLER, Deborah (et. alli). Class Action Dilemmas - pursuing public goals for private gain. Santa Monica, California: Ed. RAND, 2000.

LANDERS, William M.; POSNER, Richard A. The private enforcement of law, Journal of Legal Studies, n.4, 1975.

LEMOS, Margareth H.; MINZNER, Max. For-Profit public enforcement, Harvard Law Review, n. 127, 2014.

LEONEL, Ricardo de Barros. Manual do Processo Coletivo. 2. ed. São Paulo: RT, 2011.

LESLIE, Christopher R. The Need to Study Coupon Settlements in Class Action Litigation, Georgetown Journal of Legal Ethics, n.18, 2005.

MANKIW, Gregory. Principles of Microeconomics. $7^{\text {th }}$ ed., Nashville, Tenessee: SouthWestern College Pub, 2014.

MARINONI, Luiz Guilherme; ARENHART, Sérgo Cruz. Prova, 2ª ed, São Paulo: Saraiva, 2014.

MAZZILLI, Hugo Nigro. O inquérito civil, São Paulo: Editora Saraiva, 1999.

MENDES FERREIRA, Gilmar, Passado e Futuro da Súmula Vinculante: considerações à luz da Emenda Constitucional $n^{\circ}$ 45/04, in Reforma do Judiciário 353 (2005).

NAGAREDA, Richard A. Mass Torts in a World of Settlement, Chicago, Illinois: University Of Chicago Press, 2007.

OLSON, Mancur. The logic of collective action: public goods and the theory of groups, Harvard Economic Studies, V. CXXIV, 1965.

POSNER. Richard A., Economic Analysis of Law. $7^{\text {th }}$ ed., New York, New York: Aspen Publishers, 2003.

REDISH, Martin H.; JULIAN, Peter; ZYONTZ Samantha. Cy Press Relief and the Pathologies of the Modern Class Action: A Normative and Empirical Analysis, Florida Law Review, n.62,2010.

ROSENBERG, David. A sampling-based system of civil liability, Theoretical Inquiries in Law, Vol. 15, Issue 2, June 2014.

Class Actions for Mass Torts: Doing Individual Justice by Collective Means, Indiana Law Journal, n.62, 1987.

ROSENBERG, David; SHAVEL, Steven. A Model in Which Suits Are Brought For Their Nuisance Value, International Review of Law and Economics, n.5, 1985.

RUBENSTEIN, William B. A Transactional Model of Adjudication, Georgetown Law Journal, n.89, 2001.

. The Largest Fee Award - ever!, Class Action Attoneys' Fees

Digest, September, 2008, available at http://www.billrubenstein.com/writing.html. 
Why Enable Litigation? A Positive Externalities Theory of Small Claims Class Actions, 74 UMKC Law Review, n.74, 2006.

SERPA, Pedro Ricardo, Indenização Punitiva, unpublished masters' degree dissertation; University of São Paulo (Brazil) - 2011, available at http://www.teses.usp.br/teses/disponiveis/2/2131/tde-15052012-102822/pt-br.php.

SHAVELL, Steven. Foundations of Economic Analysis of Law. Cambridge, Massachusetts: Belknap Press, 2004.

The social versus the private cost to bring suit in a costly legal system, Journal of Legal Studies, n.11, 1982.

SHERMAN, Edward F. Consumer Class Action: Who Are the Real Winners? Maine Law Review, n.56, 2004.

TAVARES, André Ramos. A Súmula Vinculante na Emenda Constitucional $n^{\circ}$ 45/04, in Reforma do Poder Judiciário no Brasil Pós-88, São Paulo: Saraiva, 2005.

THOMPSON, Barton H., The Continuing Innovation of Citizen Enforcement, University of Illinois Law Review, vol. 2000, n.1, 2000.

VIEIRA, Fernando Grella A Transação na Esfera da Tutela dos Interesses Difusos e Coletivos: Compromisso de Ajustamento de Conduta in Ação Civil Pública: lei 7.347/1985 - 15 anos. MILARÉ, Édis (Coord.). 2. ed. São Paulo: Revista dos Tribunais, 2002.

YEAZELL, Stephen C. From medieval group litigation to the modern class action. New Haven: Yale University Press, 1987. 